\title{
9. Together in Death: Demography and Funerary Practices in Contemporary Multiple Interments in Irish Medieval Burial Grounds
}

\author{
EILEEN MURPHY AND COLM DONNELLY
}

\begin{abstract}
Murphy, E. and Donnelly, C. 2018. Across the Generations: The Old and the Young in Past Societies. AmS-Skrifter 26, 119-142, Stavanger. ISSN 0800-0816, ISBN 978-82-7760-181-6.

Contemporary multiple interment is a minority burial practice occasionally encountered in Medieval Christian burial grounds that is suggestive of the death of two or more individuals at the same time followed by a conscious decision by the living to bury those individuals together. The study reviews the evidence from thirty-one Irish burial grounds (spanning AD 300 to 1700 ) to explore the nature of the demographic combinations apparent in these contemporary multiple interments. Drawing upon information gleaned from contemporary historical sources, an attempt will be made to proffer possible scenarios to account for the different demographic configurations apparent in the burials. Funerary practices, in particular, positioning of the bodies, will be explored to see if insights can be gained concerning the nature of the potential social relationships that may have existed between those interred together in each grave. The findings from Ireland will be compared to those of studies of similar burials in AngloSaxon England.
\end{abstract}

Keywords: Minority burial practice; emotion; double burial; community; generational and inter-generational relationships

Address: Archaeology and Palaeoecology, School of Natural and Built Environment, Queen's University Belfast, Belfast BT7 1NN, Northern Ireland. Emails: eileen.murphy@qub.ac.uk; c.j.donnelly@qub.ac.uk

\section{Introduction}

The genesis of this study lies in a poignant conversation concerning the death of an elderly Irishman in 2015. The story stuck in our minds because the man did not go into his coffin alone - sadly a double tragedy had struck his family and he was accompanied by the remains of his grandson who had been born prematurely at around twenty weeks gestation. This powerful juxtapositioning of the remains of a grandfather and his baby grandson in death finds resonance with the double or triple burials that are occasionally encountered during the excavation of Medieval Irish burial grounds. The associated communities had evidently made a conscious decision to bury these individuals together in the same grave and we decided to explore the nature of the circumstances that may have led to this situation and its associated decision-making process. We wondered if it would be possible to find potential evidence for grandparents and their grandchildren in the burial record for Medieval Ireland. To this end, we reviewed the evidence from some thirty-one Medieval burial grounds (collectively spanning the centuries from AD 300 to AD 1700) to explore the nature of the demographic combinations apparent in such contemporary multiple interments.

The treatment of human dead, in both past and present contexts, invariably involves the agency of the living although undoubtedly is also related to the identity of the deceased. The provision of a final resting place for the deceased is usually a carefully considered process that would have taken time to execute and it facilitated the repositioning of the dead within a society (Hertz 1905, 48-9). Populations around the world have treated the corpse in many different ways that involve its physical manipulation and processing and the deliberate arrangement of the remains within the grave, the use of a variety of burial repositories, the provision of particular grave goods, as well as spatial segregation for certain groups (Parker Pearson 2003, 5-15). Following an archaeothanatological approach, we explored the nature of the physical relationship between the remains of the individuals within each grave. The purpose of this approach was to ascertain how those who died at, or around, the same time were treated and to investigate if this could provide insights concerning the connections that may have existed between the individuals during life. The discovery of two or more 
individuals deposited simultaneously within a shared grave provides a rare opportunity to explore the 'death event' of these individuals. Evidently such an action was considered an appropriate response by the host community - a conscious, intentional decision had been taken to provide these people with a form of burial rite that was different to the norm (see Crawford 2007, 84). In the context of Medieval Christian Ireland this norm comprised interment in an individual grave in an extended, supine position with the head to the west; in the examples included in this study, however, the individuals were evidently not buried alone and, as such, do not conform to the societal norm.

Contemporary multiple burials have been identified in Medieval Christian cemeteries throughout Europe, such as in Poland (Gardeła and Duma 2013, 317-18) and Denmark (Jark Jensen 2017, 205), but the most comprehensive reviews of multiple burial practices have been undertaken on those of Early Anglo-Saxon (c. 5-7th century) date in England. Stoodley (2002) reviewed forty-six cemeteries with evidence of multiple burials and found that the majority of multiple burials were contemporary (70.6\%) as opposed to consecutive. Similar to the current study, his research involved an examination of the demographic combinations evident in the multiple burials. He identified that most of contemporary multiple burials contained the remains of two individuals (89.0\%), with smaller numbers containing as many as five bodies. When he scrutinised the age and sex combinations within the contemporary double burials he found that adultjuvenile combinations predominated $(57.3 \%$; $63 / 110)$, with adult-only $(32.7 \%$; 36/110) combinations being relatively well represented and juvenile-only combinations occurring infrequently $(10.0 \% ; 11 / 110)$. He also found that juveniles were more likely to be buried with adult females $(55.6 \%$; 35/63) rather than males $(44.4 \%$; 28/63), while male-female combinations predominated $(67.8 \% ; 19 / 28)$ among the adult-only pairings. He concluded that these multiple burials were a complex minority burial practice that may have involved the interment of family members together in some cases but cautioned that other explanations were also possible. He highlighted the fact that many of the burials had unusual features that separated them out as being different from the single graves within the same cemeteries. He was of the view that it was probably a rare occurrence for two members of the same community to die at the same time and that it may have evoked a number of ritual responses to help ensure that no further deaths ensued (Stoodley 2002, 120).
Crawford (2007) undertook a study of the same corpus of Anglo-Saxon burials but focused on those that contained the remains of an adult and child. She considered the interpretation that such pairs might represent natural attrition as a consequence of disease or the reflection of family bonds. She observed a number of distinct characteristics in these burials, however, that led her to a different conclusion - that the child's body was viewed as an 'object' that added value to the adult who had the dominant identity within the burial. This interpretation was based on the fact that the child was often buried prone or in an unusual position, such as beneath the head in the case of one woman. In addition, the accompanying children were all aged less than nine years and were generally associated with less valuable grave goods than the associated adult. It is important to appreciate that Early Anglo-Saxon England would have operated under very different religious and social systems to Medieval Ireland; society in Ireland would have operated under the Brehon Laws which were both earlier and different to the systems of Saxon or Roman Law in operation in England (Ginnell 1993 [1894], 2-7). As such, the nature of the contemporary multiple burial practices evident from both Britain and Ireland may not necessarily be the same and this is a theme that will be further explored in the current study.

\section{Historical Context}

The burial grounds included within the study span the entire Medieval period in Ireland (c. AD 450 through to c. AD 1600), with some deriving from burials grounds that include Later Iron Age burials. To successfully interpret the osteoarchaeological and burial evidence, however, it is first necessary to provide a brief overview of the structure of Medieval Irish society during this time in order that we can understand the cultural context in which these multiple burials occurred. While some may include burials that date to the transitional period from paganism to Christianity it is considered that the vast majority of the cases were Christian, given that they generally conform to a typical Christian burial configuration and were discovered in association with other definite Christian burials.

Early Medieval Ireland was divided into kingdoms which ranged in scale from those that were small local units (túath) to substantial provincial kingdoms (cóiceda). Society operated under two fundamental bonds - the bond between a king and his people and the bond of familial kinship (Bhreathnach 2014, 40, 48). We are fortunate that many law tracts and other 
documents exist from this period which provides insights concerning the structure of society at all levels. The basic unit was the fine which operated at the levels of both nuclear family as well as extended family within a túath. The members of a túath lived in a particular territory, with its land divided in a manner that was beneficial for the community as a whole; sections were allotted respectively to the king, public officers and freemen, while an area was set aside for the poor, old and physically impaired, and another section was considered common ground for the use of all members, including slaves (Ginnell 1993 [1894], 102-3, 111-12).

The nature of marriage also meant that members of a túath were closely entwined - polygamy was accepted and a man could have a chief wife and a concubine. Both paternal and maternal kin were involved in marriage alliances and, depending on the circumstances, could have a say in the rearing of any resultant offspring (Kelly 1988, 70-1). Children in the free classes were frequently fostered; this could happen when they were infants but most commonly seems to have occurred around the age of seven years. The idea of the practice was to educate children for their roles in adulthood but it was also considered beneficial to both the child and their family since it enabled them to form emotional and political bonds with their foster family, a situation that was of mutual benefit to both parties (Fitzsimons 2001, 141; Ní Chonaill forthcoming, 10-12). The overall image provided by our historical sources is one of a highly structured and sophisticated society with close knit bonds between the members of the túath that extended well beyond the nuclear family into the broader kin group.

An integral component of a túath would have been the ferta or ancestral burial place, and generations of burials would have occurred within such a cemetery with allegiance to a kin group expressed through this continuity of burial in one location (Charles-Edwards 1992, 76). Many such cemeteries would have had their roots in the prehistoric period but they seem to have continued in use through to the seventh century and took a variety of forms, including circular ditched enclosures, ring-barrows, and mounds (Bhreathnach 2014, 143-4). During the transition from paganism to Christianity in the fourth and fifth centuries AD it seems that pagans and Christians alike were buried within fertae. By the seventh century AD, however, there appears to have been change and some fertae were abandoned, while others were reconstituted as consecrated burial grounds under the control of the Christian church (Bhreathnach 2014, 144-5). The latter would still have been located within the túath, however, and would have continued to contain the buried remains of members of the local fine and the territory's extended kin group.

A review of the dating evidence from the cemeteries that were found to have included contemporary multiple interments included in the current study (23/31 - see below) indicates that the majority $(15 / 23)$ had been abandoned by the twelfth century, with a further three sites (Carrowkeel, Parknahown and Treanbaun) abandoned by the mid-thirteenth century. The end of burials at these eighteen sites may be a result of the reorganisation and reform that commenced within the Medieval Irish church in the early twelfth century and included the formation of territorially defined parishes under a diocesan system (Downham 2018, 284). At Ballyhanna, Co. Donegal, the site seems to have witnessed a reduction in the level of burial activity in the period between the early eleventh century and the second half of the twelfth century before burial activity increased again, with a stone church constructed in the mid-thirteenth century. The catalyst that brought the site back into use may have been its use as a chapel-ofease within the new parish of Inishmacsaint in the diocese of Clogher (McKenzie et al. 2015, 162). A similar situation may have occurred at Drumkay, Co. Wicklow, and at Ballykilmore 6, Co. Westmeath, both of which continued in use through to the end of the Medieval period. While Ballyhanna remained within the Gaelicruled territory of the O'Donnells during this time, however, the former two sites were now located within lands appropriated by Anglo-Norman adventurers in the late twelfth and early thirteenth centuries. This introduces the possibility that a percentage of the dead within these graveyards are the bodies of serfs and tenants who came across to Ireland as economic migrants to work on the Anglo-Norman (or Anglo-Irish) estates (Downham 2018, 214-15) but processes of acculturation and assimilation were in operation as well, given that many Gaelic people remained as workers within the conquered lands. As such, by the late fourteenth century a process of hybridisation was at play in the Anglo-Irish territories, and hence the need for the ultimately unsuccessful - Statutes of Kilkenny in AD 1366 (Curtis and McDowell 1943, 52-9). This required the English in Ireland to set themselves apart from their Gaelic neighbours, given the authority's concerns that the former were 'going native' as a result of such interaction.

The historical sources for Medieval Ireland tend to suggest that it was considered appropriate for members 
of the same kin group to be buried together; this was particularly the case if they had died simultaneously. Both Gaelic and Anglo-Irish sources provide examples of such instances in relation to particular members of society, including 'kings, bishops, warriors, soldierboys and royal women' (Fry 1999, 149). While some of the individuals included in the current study may have fallen within these groups it is probable that the majority came from the ordinary levels of society, for whom the historical records are largely silent.

\section{Materials and Methods}

The burial records for some thirty-one burial grounds that ranged in date from approximately AD 300 to 1700 were examined. Many of the sites were discovered and investigated as part of development work for new roads. As such, the excavations were predominantly associated with modern centres of population, primarily in mid Leinster and the Midlands. A range of site types were included from cemeteries associated with prehistoric sites to settlement cemeteries to those associated with ecclesiastical foundations. All of the simultaneous burials appear to have been those of Christians since they generally adhered to standard Christian burial practices - interment in an extended supine position with the head to the west (see below). A review of the radiocarbon dates (at two sigma) associated with the burials revealed that they spanned the entirety of the Medieval period, with the earliest represented by Conversion period burials at sites in County Meath - Skeletons 853 and 854 at Raystown (AD 320-470; Wk-16823; Seaver 2016, appendix 1) and Skeletons 5 and 6 at Claristown 2 (AD 330-580; Beta-185351; Russell 2004, 135) - and the latest derived from a simultaneous burial in the churchyard at Ballyhanna, Co. Donegal (Sk 823 and Sk 824 - AD 1409-1450; UBA-14992) (McKenzie and Murphy 2018, appendix 1). Furthermore, within the burial site at Parknahown 1, Co. Laois, radiocarbon dating of five of the six simultaneous double burials revealed they were spread across the Medieval period, with one dating to the sixth-seventh centuries (Sk 003 and Sk 004), another to the seventh-eighth centuries (Sk 474 and Sk 475) and three from the ninth to eleventh centuries (Sk 121 and Sk 123; Sk 795 and Sk 797; Sk 1025 and Sk 1026) (O’Neill 2009, 312-13, appendix 3).

In practically all cases the simultaneous nature of the burials was identified during the course of the excavations. In the current study the available context records, photographs and plans were consulted and Duday's (2009) archaeothanatology approach was followed so that the physical relationship between the individuals in each contemporary multiple burial could be examined. This approach involves assessment of the changes that a corpse undergoes from the time of death from both biological and social perspectives; decomposition processes are considered in conjunction with funerary practices (Duday 2009, 13). A variety of successive multiple burial forms were encountered in the Medieval burial grounds but only definite contemporary multiple burials that contained the remains of two or more individuals interred at the same time were included in the study (Stoodley 2002, 106; Sprague 2005, 77-8). As Duday (2009, 73-6) cautions it does need to be appreciated that some of the apparent contemporary burials may have occurred as consecutive deposits made within a very short time period, before the ligaments of the labile joints that break down most quickly had done so, but this difference would be impossible to detect unless subtle evidence of soil disturbance was recorded during the excavation (Knüsel 2014, 45).

Cases of multiple burial in which the individuals were not contemporary interments have been excluded from the current study. At Ballykilmore, Co. Westmeath, for example, cases of 'multiple vertical burial' were identified in the earthen grave cuts and were interpreted as successive burials within family plots (Channing 2014, 33). A triple interment at Drumkay Glebe, Co. Wicklow, was also considered to provide evidence for the deliberate re-use of an earthen grave as a family plot. In this case the initial burial was that of an adult and the remains of an older child appear to have been added at a later date and deliberately positioned adjacent to the left side of the adult, while an infant had been laid with its head on the right side of the adult's pelvis (O'Donovan 2016, 202, fig. 12.18). Similarly, at Bushfield/Maghernaskea, Co. Laois, some fourteen of the fifty-six burials were found to contain the remains of at least two individuals; these were interpreted as evidence for the re-opening of existing graves so that further individuals could be interred at a later date (Wiggins and Kane 2009a, 119). When the earlier remains are in a disarticulated state it is clear that a long period of time had elapsed between the initial and subsequent interments. At Raystown, Co. Meath, space for burial appears to have been scarce and there was ample evidence that disturbance of older earthen graves had resulted in the inclusion of disarticulated remains in later burials. In some cases, the disturbed bones were deliberately arranged as was evident in the burial of an older woman who had femora from a disturbed burial placed lying across her abdomen (Fibiger and Seaver 
2016, 83, fig. 3.16). In the burial ground at Mount Gamble, Co. Dublin, three individuals - an older child of 8-9 years, a younger child of two years and a 6-monthold infant - interred within a single earthen grave were considered to have been buried over a relatively short period of time - perhaps a single season. All three displayed lesions characteristic of scurvy and the two younger children appeared to have been deliberately positioned so they each lay on one of the older child's shoulders. It is thought that these two individuals may have been contemporary deaths that were added to the grave of the older child (O'Donovan 2005, 145; 2016, $28-9$, fig. 1.14). Given the complexity of this grave and the possible presence of both successive and contemporary burials it has been excluded from the current analysis. Another ambiguous case omitted from the current study is the burial of a young woman and a set of twins from Ballyhanna, Co. Donegal. It may be the case that both infants and their mother died during or immediately after the birthing process and were buried together in their grave. Alternatively, it may have been the case that the babies were not delivered prior to the mother's death. Detailed consideration of the excavation archive and archaeothanatological analysis has not enabled a definite conclusion to be reached at this stage and, as such, we cannot be certain which scenario was played out at this Medieval Gaelic cemetery.

The preceding examples generally involved successive burials in earthen graves, some of which had tokenistic stone lining around the margins of the grave, but stone formed a more substantial component of a proportion of the burials at Owenbristy, Co. Galway, where twenty-six graves had slab-lined walls and were also lidded with slabs. Seven of these slab-lined burials contained between two and four individuals in a single grave. Interestingly, in the five cases when children were included in multiple burials they were always positioned lying on top of the adult or older child; there may have been a desire to inter a child with an older individual who had died previously. A similar pattern was evident in the five multiple burials in earthen graves at the site (Lehane et al. 2010, 149). Since there was such a high level of successive multiple burials at Owenbristy, and clear evidence for the re-use of both forms of grave, this burial ground was excluded from the analysis.

A number of the descriptions of the burials describe the position in which the skull is facing but, in the absence of clear views of the cervical vertebrae in the associated photographs, these are not considered to be definitive and may have been due to post-mortem movement of the skull which is generally unstable due to its spherical shape (see Duday 2009, 17-19). It should be noted that the names of the body parts, as opposed to those of the bones, have been included in the summary descriptions of the body positions in Tables 4-7 for ease of interpretation by non-osteoarchaeologists.

The methods used by all of the osteoarchaeologists whose data is referred to in the paper followed standard methods and were thus comparable. Adult age and sex determination followed the recommendations of Buikstra and Ubelaker (1994), while age-at-death values for juveniles were determined using a combination of epiphyseal fusion data, the diaphyseal lengths of long bones, dental eruption and dental mineralisation (Moorrees et al. 1963; Smith 1991; Scheuer and Black 2000). To enable comparison of the demographic trends the age-at-death categories across the sites were categorised into recognised age bands, with adults being identified as young (18-35 years), middle-aged (35-50 years) or older (50+ years). The term juvenile refers to all individuals aged less than eighteen years and they were sub-divided into five age groups - full term/neonates (37-44 gestational weeks), infants (one month to one year), younger children (1- 6 years), older children (6-12 years) and adolescents (12-18 years) (Scheuer and Black 2000, 468-9).

\section{Overall Trends}

Some twenty-three of the thirty-one sites investigated in the current study were found to contain definitive evidence of one or more burials that had involved the simultaneous interment of at least two individuals (74.2\%; 23/31; Fig. 1; Table 1). ${ }^{1}$ When the total number of individuals afforded simultaneous burial with one or more other individuals is examined in relation to the total number of individuals included in the study it is evident that this is very much a minority burial practice; only $1.6 \%(85 / 5,218)$ of individuals shared a grave with others who had died around the same time (see Table 1).

A total of forty-two contemporary multiple burials were identified, a notable majority of which comprised double burials $(97.6 \%$; 41/42); only one case that had involved the contemporary interment of three individuals was evident. This consisted of the burial of three adult females in a ring-ditch complex at Morett, Co. Laois, and no evidence as to cause of death was evident in their remains (Cotter 2011, 16).

It was possible to sub-divide the multiple burials into three demographic groupings - those that contained 
Table 1: Summary of the proportions of contemporary multiple burials and the key features of the sites included in the study.

\begin{tabular}{|c|c|c|c|c|c|c|}
\hline Site & County & Date range & Type of site & $\begin{array}{c}N \\
\text { contemporary } \\
\text { multiple } \\
\text { burials }\end{array}$ & $\begin{array}{c}N \\
\text { contemporary } \\
\text { deaths/total } \\
\text { individuals }\end{array}$ & Sources \\
\hline Ardsallagh 1 & Meath & AD 400-700 & $\begin{array}{l}\text { ring-ditch in } \\
\text { prehistoric } \\
\text { settlement }\end{array}$ & 3 & $20.0 \%(6 / 30)$ & $\begin{array}{l}\text { Clarke and Carlin 2008a; 2009; } \\
\text { Randolph-Quinney } 2008\end{array}$ \\
\hline Augherskea & Meath & AD 400-900 & settlement cemetery & 1 & $1.1 \%(2 / 187)$ & Powers 2004; Baker 2010 \\
\hline Ballyhanna & Donegal & $A D 650-1650$ & churchyard & 3 & $0.5 \%(6 / 1296)$ & McKenzie and Murphy 2018 \\
\hline Ballykilmore 6 & Westmeath & AD 400-1300 & $\begin{array}{l}\text { enclosed cemetery } \\
\text { then churchyard }\end{array}$ & 2 & $0.5 \%(4 / 797)$ & $\begin{array}{l}\text { Channing 2009; 2014; Randolph- } \\
\text { Quinney } 2009\end{array}$ \\
\hline Baysrath & Kilkenny & $A D 400-650$ & $\begin{array}{l}\text { linear cemetery } \\
\text { associated with } \\
\text { ring-ditch complex in } \\
\text { prehistoric setting }\end{array}$ & 2 & $9.3 \%(4 / 43)$ & Channing 2012; Svensson 2012 \\
\hline Bettystown & Meath & $A D 400-600$ & $\begin{array}{l}\text { unenclosed } \\
\text { cemetery }\end{array}$ & 2 & $6.6 \%(4 / 61)$ & Eogan 2010 \\
\hline $\begin{array}{l}\text { Bushfield/ } \\
\text { Maghernaskea }\end{array}$ & Laois & $A D 550-700$ & settlement cemetery & 2 & $6.7 \%(4 / 60)$ & $\begin{array}{l}\text { Keating 2009a; Wiggins and Kane } \\
\text { 2009a }\end{array}$ \\
\hline Camlin 3 & Tipperary & AD $650-1000$ & settlement cemetery & 2 & $2.6 \%(4 / 152)$ & Flynn 2011; Svensson 2011 \\
\hline Carrowkeel & Galway & AD $650-1250$ & settlement cemetery & 1 & $1.5 \%(2 / 130)$ & $\begin{array}{l}\text { Wilkins and Lalonde 2008; 2009; } \\
\text { Lalonde } 2009\end{array}$ \\
\hline $\begin{array}{l}\text { Church Road, } \\
\text { Lusk }\end{array}$ & Dublin & $A D 400-600$ & $\begin{array}{l}\text { monastery burial } \\
\text { ground }\end{array}$ & 1 & $25.0 \%(2 / 8)$ & O'Connell 2014 \\
\hline Claristown 2 & Meath & AD $300-700$ & $\begin{array}{l}\text { cemetery associated } \\
\text { with prehistoric cairn }\end{array}$ & 2 & $30.8 \%(4 / 13)$ & $\begin{array}{l}\text { Buckley 2004; Russell 2004; } \\
\text { Russell et al. } 2002\end{array}$ \\
\hline Collierstown 1 & Meath & AD 350-700 & ring-ditch & 1 & $3.3 \%(2 / 61)$ & Coughlan 2009; O'Hara 2009 \\
\hline $\begin{array}{l}\text { Drumkay, } \\
\text { Glebe }\end{array}$ & Wicklow & AD $600-1600$ & $\begin{array}{l}\text { enclosure then } \\
\text { churchyard }\end{array}$ & 1 & $1.1 \%(2 / 191)$ & O'Donovan 2014 \\
\hline $\begin{array}{l}\text { Faughart Lower } \\
116\end{array}$ & Louth & AD $350-1000$ & settlement cemetery & 1 & $0.3 \%(2 / 771)$ & Bowen and Dawkes 2011 \\
\hline Johnstown 1 & Meath & AD $350-1700$ & settlement cemetery & 4 & $2.0 \%(8 / 398)$ & $\begin{array}{l}\text { Clarke 2004; 2010; Clarke and } \\
\text { Carlin 2008b; Fibiger } 2008\end{array}$ \\
\hline Killeany 1 & Laois & AD 500-1000 & settlement cemetery & 1 & $2.9 \%(2 / 68)$ & $\begin{array}{l}\text { Keating 2009a; Wiggins and Kane } \\
\text { 2009a; Wiggins } 2014\end{array}$ \\
\hline Knoxpark & Sligo & AD $600-1000$ & $\begin{array}{l}\text { promontary fort and } \\
\text { enclosed cemetery }\end{array}$ & 1 & $1.9 \%(2 / 103)$ & Mount 2010 \\
\hline Morett & Laois & AD 400-600 & ring ditch complex & 1 & $75.0 \%(3 / 4)$ & Cotter 2011 \\
\hline Mount Gamble & Dublin & AD 550-1150 & unenclosed cemetery & 2 & $1.4 \%(4 / 281)$ & $\begin{array}{l}\text { O'Donovan 2005; 2016; O'Donovan } \\
\text { and Geber 2010; Geber } 2015\end{array}$ \\
\hline Parknahown 5 & Laois & AD 400-1300 & settlement cemetery & 6 & $2.8 \%(12 / 425)$ & Keating 2009b; O'Neill 2009 \\
\hline Raystown & Meath & AD 300-950 & settlement cemetery & 1 & $2.2 \%(2 / 93)$ & $\begin{array}{l}\text { Fibiger and Seaver 2016; Seaver } \\
2016\end{array}$ \\
\hline $\begin{array}{l}\text { Saw Pit Lane, } \\
\text { Tuam }\end{array}$ & Galway & AD $550-1700$ & $\begin{array}{l}\text { monastery burial } \\
\text { ground/ churchyard }\end{array}$ & 1 & $13.3 \%(2 / 15)$ & Delaney 2012 \\
\hline Treanbaun & Galway & AD $650-1250$ & settlement cemetery & 1 & $6.7 \%(2 / 30)$ & $\begin{array}{l}\text { Muñiz Pérez 2009; Lehane et al. } \\
2010\end{array}$ \\
\hline Totals & & & & 42 & $1.6 \%(85 / 5,218)$ & \\
\hline
\end{tabular}




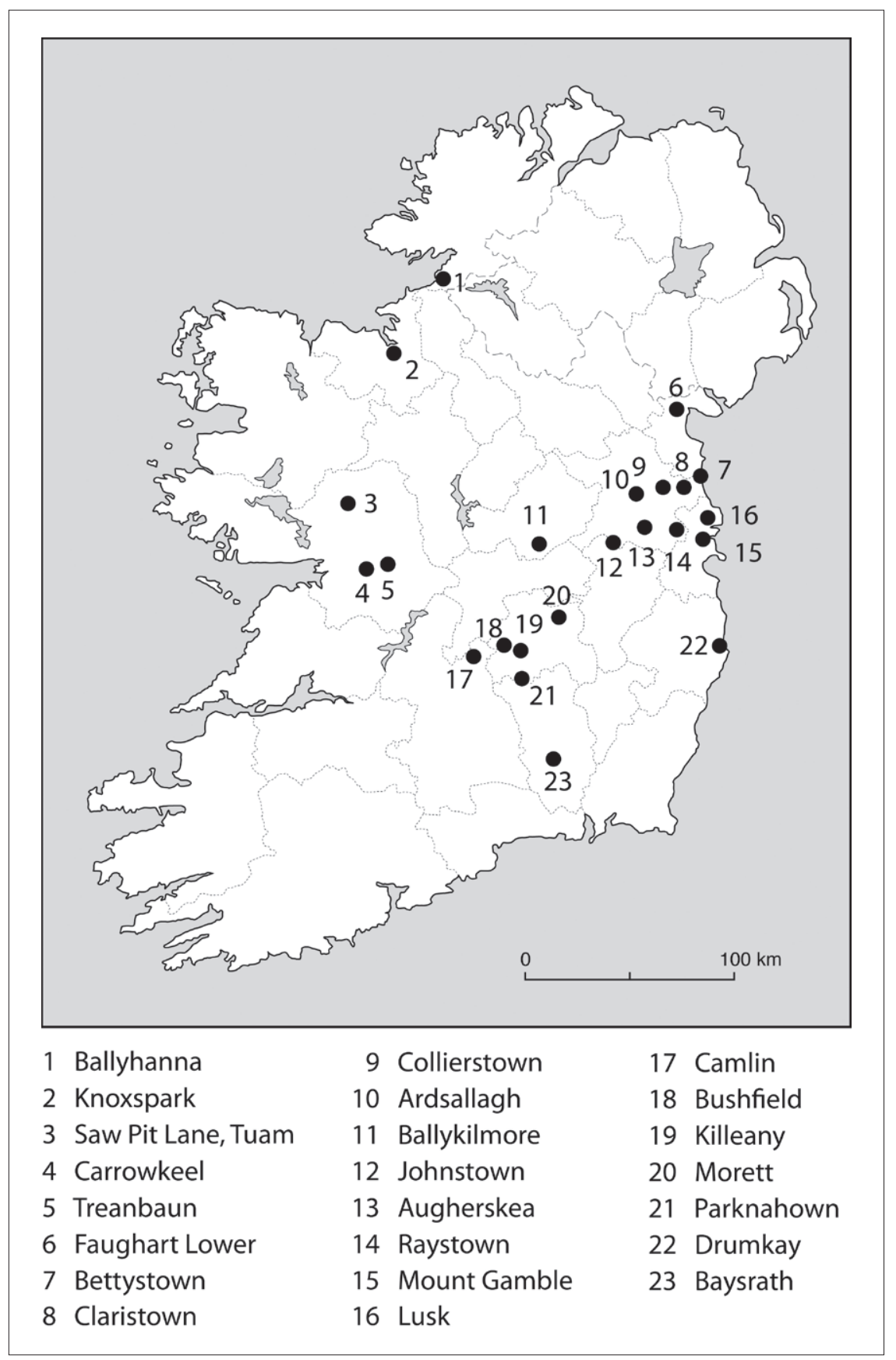

Figure 1: Map showing the location of the sites which contained the remains of one or more contemporary multiple burials (prepared by Libby Mulqueeny).

adults only, those that included juveniles only, and those in which the remains of an adult and juvenile were recovered. When the proportions of the three burial configurations were examined it was evident that contemporary multiple burials with an adult and child greatly predominated $(50.0 \% ; 21 / 42)$, with adult-only $(26.2 \% ; 11 / 42)$ and juvenile-only burials $(23.8 \% ; 10 / 42)$ occurring in notably lower, but near equal, frequencies. This trend differs somewhat to that found in Stoodley's (2002) review of Early Anglo-Saxon contemporary multiple burials. While the preponderance of adultjuvenile combinations $(57.3 \%)$ is similar, juvenile-only burials $(10.0 \%)$ occurred much more infrequently and adult-only burials were well represented (32.7\%). This difference may indicate that juveniles were viewed differently in the Anglo-Saxon World compared to that of Medieval Ireland. In the discussion that follows each of the three age categories will be considered in an effort to discern evidence of social interactions within, and across, the various generations.

\section{Adult-Only Burials}

A total of eleven contemporary multiple burials were identified that contained only adults. It was possible to determine the sex of all individuals in nine instances 
Table 2: Summary of the weapon trauma evident in individuals buried in contemporary multiple burials.

\begin{tabular}{|c|c|c|c|c|c|}
\hline Site & Context & $\begin{array}{l}\text { C14 date } \\
\text { (2 sigma) }\end{array}$ & $\begin{array}{l}\text { Age-at- } \\
\text { death } \\
\text { (years) }\end{array}$ & Weapon injuries & Interpretation \\
\hline \multirow[t]{2}{*}{ Augherskea } & Sk 2 & $\begin{array}{l}\text { AD 674-778 } \\
\text { (UBA-28177) }\end{array}$ & $35-50$ & 3 or 4 sharp force cuts on cervical vertebrae & Decapitation - possibly execution \\
\hline & Sk 165 & & $35-50$ & Missing head and neck & $\begin{array}{l}\text { Decapitation - head removed as } \\
\text { trophy }\end{array}$ \\
\hline \multirow[t]{2}{*}{ Ballyhanna } & Sk 289 & & $18-35$ & Sharp force cut on $\mathrm{R}$ femur and $\mathrm{R}$ patella & Violent death \\
\hline & Sk 290 & & $35-50$ & - & $\begin{array}{l}\text { Perhaps also died violently but of } \\
\text { injury to soft tissue? }\end{array}$ \\
\hline \multirow[t]{2}{*}{ Ballykilmore 6} & Sk 399 & $\begin{array}{l}\text { AD 1160-1258 } \\
\text { (UBA-8681) }\end{array}$ & $18-35$ & $\begin{array}{l}\text { Sharp force cuts on midshaft of } L \text { ulna and radius } \\
1 \text { sharp force cut on } L \text { mastoid process and } 2 \\
\text { cuts to } L \text { side of mandible } \\
4 \text { sharp force cuts to } L \text { and posterior side of } \\
\text { neural arches of cervical vertebrae } \\
\text { Series of sharp force cuts through posterior } \\
\text { scapulae and associated ribs }\end{array}$ & $\begin{array}{l}\text { Defence wound } \\
1 \text { or } 2 \text { blow(s) from behind; } \\
\text { attempted decapitation } \\
4 \text { blows from behind; attempted } \\
\text { decapitation } \\
\text { Multiple blows from behind; } \\
\text { attempted dismemberment of } \\
\text { upper limbs }\end{array}$ \\
\hline & Sk 415 & & $13-14$ & $\begin{array}{l}1 \text { sharp force cut on } L \text { mastoid process and } \\
\text { mandible } \\
3 \text { sharp force cuts to } L \text { and posterior aspects of } \\
\text { neural arches of cervical vertebrae }\end{array}$ & $\begin{array}{l}1 \text { blow from above and behind; } \\
\text { attempted decapitation } \\
3 \text { blows from above and behind; } \\
\text { attempted decapitation }\end{array}$ \\
\hline \multirow[t]{2}{*}{$\begin{array}{l}\text { Church Road, } \\
\text { Lusk }\end{array}$} & $\begin{array}{l}\text { Context } \\
\text { not stated }\end{array}$ & $\begin{array}{l}\text { AD 470-570 } \\
\text { (SUERC-16999) }\end{array}$ & Adult & $\begin{array}{l}\text { Multiple blade injuries including to mandible and } \\
\text { cervical vertebrae } \\
\text { Iron spearhead protruding from upper torso }\end{array}$ & 'Overkill' and decapitation \\
\hline & $\begin{array}{l}\text { Context } \\
\text { not stated }\end{array}$ & & Adult & $\begin{array}{l}\text { Multiple blade injuries including to mandible and } \\
\text { cervical vertebrae }\end{array}$ & 'Overkill' and decapitation \\
\hline \multirow[t]{2}{*}{ Knoxpark } & Sk 4 & $\begin{array}{l}\text { AD 723-962 } \\
\text { (UB-3836) }\end{array}$ & Adult & Skull not present & $\begin{array}{l}\text { Decapitation - head removed } \\
\text { as trophy }\end{array}$ \\
\hline & Sk 75 & & Adult & Skull not in anatomical position & Decapitation \\
\hline \multirow[t]{2}{*}{ Mount Gamble } & $\begin{array}{l}\text { Sk } \\
\text { CCLXXX }\end{array}$ & $\begin{array}{l}\text { AD 656-765 } \\
\text { (UB-6084) }\end{array}$ & $18-35$ & 1 sharp force cut on a $\mathrm{R}$ rib & Stab wound in back \\
\hline & $\begin{array}{l}\text { Sk } \\
\text { CCLXXXI }\end{array}$ & & $18-35$ & $\begin{array}{l}1 \text { sharp force cut on occipital } \\
1 \text { sharp force cut on atlas } \\
1 \text { sharp force cut through axis and angles of } \\
\text { mandible } \\
2 \text { sharp force cuts on } 1 \mathrm{R} \text { and } 1 \mathrm{~L} \text { ribs }\end{array}$ & $\begin{array}{l}\text { Related to decapitation } \\
\text { Partial decapitation } \\
\text { Decapitation } \\
\text { Stab wound to chest }\end{array}$ \\
\hline
\end{tabular}

and seven were found to contain pairs of males, while the remaining two contained only females. It is interesting that no mixed sex pairings were identified thereby suggesting that none of the multiple burials are likely to be those of married couples. This may not be a particularly surprising situation, however, since the Irish Medieval historical sources indicate that women could choose where they wished to be buried. For example, a law laid out in the Cáin Adomnán (AD 697) indicates that women could choose their own burialplace and this is also evident within the Late Medieval sources which indicate that upper class women could be buried with their own families as opposed to those of their husbands (Fry 1999, 172). Stoodley $(2002,113)$ found that mixed sex pairs of adults $(52.8 \%$; 19/36) predominated in the corpus of simultaneous double burials from Early Anglo-Saxon England; this again is suggestive of notable differences in the constitution of simultaneous multiple burials in Ireland and England.

No obvious cause of death was apparent in six of the adult multiple burials but it was noteworthy that in five of the male multiple burials one or both individuals displayed evidence of unhealed weapon trauma; it is clear these individuals had suffered violent deaths 
(Table 2). In four of the cases, one or both individuals had been decapitated; the remains of an adult male and an adolescent male in a double burial at Ballykilmore 6 also displayed evidence of decapitation (Channing 2014, 33; Randolph-Quinney 2009, 64-5) (see below). The pairing of decapitated individuals in the double burials is suggestive that some of the individuals had been formally executed. While skeletal evidence for violent death across Medieval Ireland has been shown to be relatively low (in the range of $1 \%$ to $3.4 \%$ ) there are numerous examples in the historical sources that allude to violence; these, however, largely relate to the upper echelons of society (Donnelly and Murphy 2018). It is interesting that the heads of two of the individuals included within the double burials - that of Sk 165 from Augherskea (Baker 2010, 5) and Sk 4 from Knoxpark (Mount 2010, 192) - were missing and these may have been removed as trophies of war. The significance of the head appears to have extended throughout the Medieval period (see e.g. Meyer 1906, 5) and removal of the head was all the more significant because Medieval Christians believed that a body lacking a head would be unable to undergo physical resurrection on the Day of Judgement. Body parts of persons of particular importance could also be buried in separate locations if they were viewed as relics (Fry 1999, 97-9) but, given the lack of evidence that the headless individuals from Augherskea and Knoxpark were of high status, it seems more probable their heads had been retained for negative reasons associated with violence.

It is possible that the adults in these double burials were buried together as a matter of convenience since they had died at the same time. The burials were all very respectfully arranged, with the heads generally lying adjacent to one another in a westerly direction and the bodies lying parallel in a largely extended supine position as would be expected for Christian burials. As such, it would seem that even those who had died violently had been interred by friends rather than foes. As discussed above, the structure of Irish society meant that members of a community had close bonds and it may simply have been considered appropriate to bury those who died in a violent incident together. Indeed, Fry (1999, 150-1) provides a range of examples from Irish Medieval historical accounts that involve the simultaneous interment in shared graves of both elite and non-elite soldiers who had fallen at the same time. It is also possible, however, that some of these double burials comprise adult family members who died together. This would seem all the more likely in instances where glimpses of deliberate physical connections between those interred appear to have been intentionally made by those responsible for their burial.

It was possible to examine the body position of nine of the adult-only double burials (Table 3). In eight of these cases the bodies were physically connected, the only exception having been the burial of three women at Morett who lay alongside one another in a large, shallow grave (Cotter 2011, 16). In six of the contemporary burials the physical connection involved overlapping adjacent arms. It could be argued that this type of overlap simply occurred for practical reasons to ensure that both bodies fitted within the grave cut. In addition to having had overlapping arms, the two decapitated individuals buried together at Church Road, Lusk, appear to have been deliberately positioned holding hands (O'Connell 2014, 180, fig. 11.9). This would seem to be a very intimate arrangement and it seems reasonable to suggest these two men were close relatives or friends.

Two of the burials displayed physical connections that were notably extensive. The two adult males in a

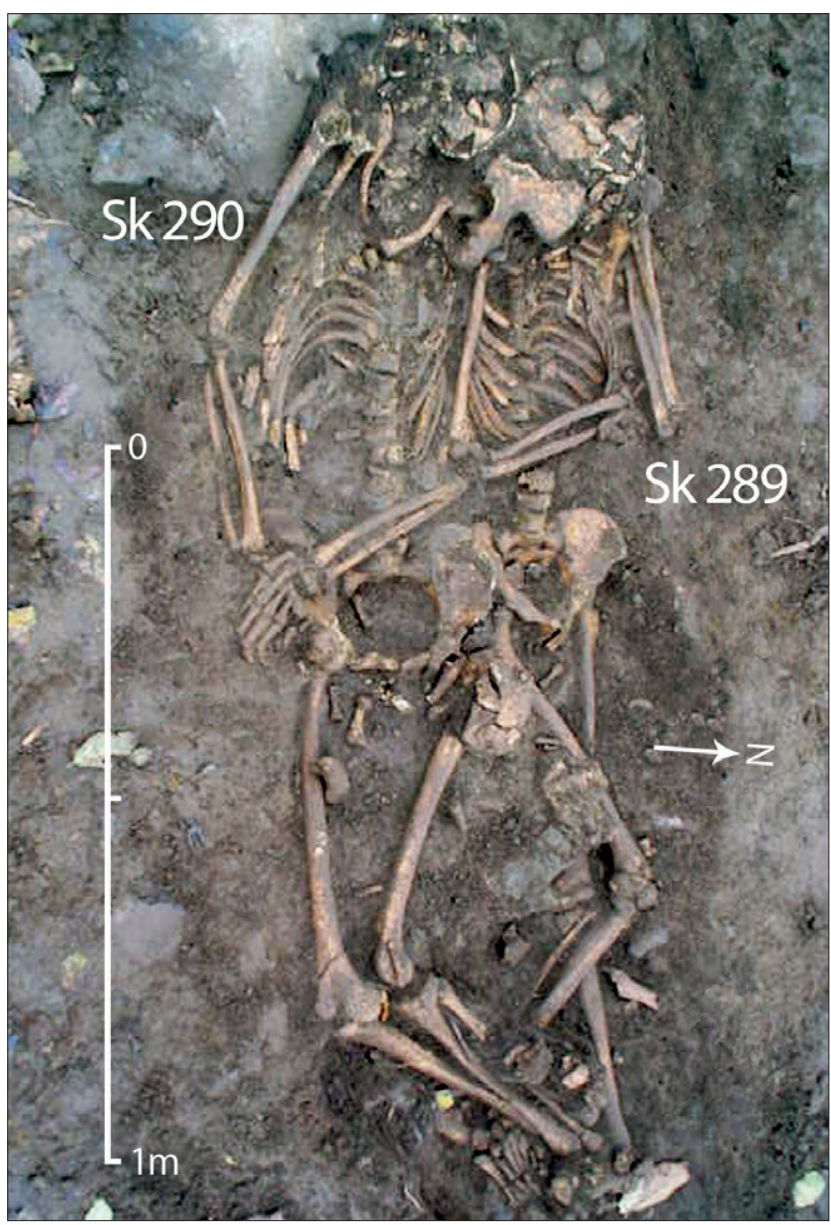

Figure 2: Contemporary double burial of two adult males (Sk 289; 18-35 years and Sk 290; 35-50 years) - from Ballyhanna, Co. Donegal. Unhealed sharp-force trauma was evident in the remains of Sk 289 (Photo by Irish Archaeological Consultancy Ltd, annotation by Libby Mulqueeny). 
Table 3: Summary of the demographic and main burial characteristics apparent in contemporary multiple burials that contained only adults. All bodies were lying in an extended supine position with the head in a westerly direction unless stated otherwise (see Sprague 2005, 86-9 for method of recording angles).

\begin{tabular}{|c|c|c|c|c|}
\hline Site & Context & $\begin{array}{l}\text { Age-at- } \\
\text { death } \\
\text { (years) }\end{array}$ & Sex & Physical relationship between individuals \\
\hline \multirow[t]{2}{*}{ Augherskea } & Sk 2 & $35-50$ & Male & \multirow{2}{*}{$\begin{array}{l}\text { R arm of Sk } 165 \text { overlay L arm of Sk } 2 \\
\text { Bodies touched at feet } \\
\text { Lateral aspects of bodies slightly raised so the individuals were } \\
\text { angled towards each other }\end{array}$} \\
\hline & Sk 165 & $35-50$ & Male & \\
\hline \multirow[t]{2}{*}{ Ballyhanna } & Sk 289 & $18-35$ & Male & \multirow[b]{2}{*}{$\begin{array}{l}\text { Body of Sk } 289 \text { tilted by c. } 45^{\circ} \text { towards L side away from Sk } 290 \\
\text { R upper arm of Sk } 289 \text { overlay L upper arm of Sk } 290 \text { to elbow } \\
\text { where they were angled at } 90^{\circ} \text { and the lower arms lay in opposite } \\
\text { directions } \\
\text { Bodies touched at pelves } \\
\text { Upper legs of Sk } 290 \text { semi-flexed at hip }\left(R 10^{\circ} ; L 20^{\circ}\right) \text { and knees } \\
\left(R 60^{\circ} ; L 50^{\circ}\right) \text { towards R side. L leg of Sk } 289 \text { extended while R leg } \\
\text { semi-flexed at hip by } 40^{\circ} \text { and at knee by } 40^{\circ} \text { towards } L \text { side } \\
\text { Lower legs of Sk } 290 \text { overlay R lower leg of Sk } 289 \text {; feet of Sk } 290 \\
\text { overlay L foot of Sk } 289\end{array}$} \\
\hline & Sk 290 & $35-50$ & Male & \\
\hline \multirow[t]{2}{*}{ Bushfield/Maghernaskea } & $\begin{array}{l}\text { Sk } 2 \\
\text { Sk } 4\end{array}$ & $\begin{array}{l}\text { Adult } \\
18-35\end{array}$ & $\begin{array}{l}\text { Indeterminate } \\
\text { Indeterminate }\end{array}$ & $\begin{array}{l}\text { Unusually large grave cut but too poorly preserved to observe } \\
\text { details }\end{array}$ \\
\hline & $\begin{array}{l}\text { Sk } 6 \\
\text { Sk } 7\end{array}$ & $\begin{array}{l}18-35 \\
18-35\end{array}$ & $\begin{array}{l}\text { Indeterminate } \\
\text { Indeterminate }\end{array}$ & $\begin{array}{l}\text { Unusually large grave cut but too poorly preserved to observe } \\
\text { details }\end{array}$ \\
\hline Church Road, Lusk & $\begin{array}{l}\text { Context not stated } \\
\text { Context not stated }\end{array}$ & $\begin{array}{l}\text { Adult } \\
\text { Adult }\end{array}$ & $\begin{array}{l}\text { Male } \\
\text { Male }\end{array}$ & $\begin{array}{l}\text { Overlap of adjacent upper arms } \\
\text { Adjacent forearms rotated so that individuals held hands }\end{array}$ \\
\hline Faughart Lower 116 & $\begin{array}{l}\text { Sk 1385A } \\
\text { Sk 1395A }\end{array}$ & $\begin{array}{l}35-50 \\
18-35\end{array}$ & $\begin{array}{l}\text { Male } \\
\text { Male }\end{array}$ & $\begin{array}{l}\text { R arm of Sk } 1385 A \text { overlay L arm of Sk } 1395 \mathrm{~A} \\
\text { Sk } 1395 \mathrm{~A} \text { lay on L side; torso of Sk } 1385 \mathrm{~A} \text { supine } \\
\text { Pelves adjacent to one another } \\
\text { Both individuals' legs were semi-flexed at the hips by approximately } \\
70^{\circ} \text {, so that the femora were parallel. Lower legs of Sk } 1395 \mathrm{~A} \text { were } \\
\text { flexed at the knees by } 120^{\circ} \text {, while those of Sk } 1385 \mathrm{~A} \text { were flexed at } \\
\text { knees by } 90^{\circ}\end{array}$ \\
\hline Knoxpark & $\begin{array}{l}\text { Sk } 4 \\
\text { Sk } 75\end{array}$ & $\begin{array}{l}\text { Adult } \\
\text { Adult }\end{array}$ & $\begin{array}{l}\text { Male } \\
\text { Male }\end{array}$ & Overlap of adjacent arms but no further details available \\
\hline Morett & $\begin{array}{l}\text { Sk } 1 \\
\text { Sk } 2 \\
\text { Sk } 3\end{array}$ & $\begin{array}{l}\text { Adult } \\
\text { Adult } \\
\text { Adult }\end{array}$ & $\begin{array}{l}\text { Female } \\
\text { Female } \\
\text { Female }\end{array}$ & $\begin{array}{l}3 \text { individuals positioned tightly beside one another but no obvious } \\
\text { overlap of bodies }\end{array}$ \\
\hline Mount Gamble & $\begin{array}{l}\text { Sk CCLXXX } \\
\text { Sk CCLXXXI }\end{array}$ & $\begin{array}{l}18-35 \\
18-35\end{array}$ & $\begin{array}{l}\text { Male } \\
\text { Male }\end{array}$ & $\begin{array}{l}\text { R upper arm of Sk CCLXXX overlay L arm of Sk CCLXXXI } \\
\text { Sk CCLXXX's R foot lay between the feet of Sk CCLXXXI } \\
\text { Sk CCLXXX was associated with 'ear muff' stones }\end{array}$ \\
\hline Parknahown 5 & $\begin{array}{l}\text { Sk } 474 \\
\text { Sk } 475\end{array}$ & $\begin{array}{l}18-35 \\
18-35\end{array}$ & $\begin{array}{l}\text { Female } \\
\text { Female }\end{array}$ & $\begin{array}{l}\text { L elbow of Sk } 474 \text { crossed over the R elbow of Sk } 475 \text { and her hand } \\
\text { touched the L side of the other woman's pelvis } \\
\text { R hand of Sk } 475 \text { lay beneath the R side of the pelvis of Sk } 474\end{array}$ \\
\hline Saw Pit Lane, Tuam & $\begin{array}{l}\text { Sk } 6 \\
\text { Sk } 7\end{array}$ & $\begin{array}{l}35-50 \\
18-35\end{array}$ & $\begin{array}{l}\text { Male } \\
\text { Male }\end{array}$ & $\begin{array}{l}\text { L upper arm of Sk } 7 \text { overlay R upper arm of Sk } 6 \\
\text { Remainder of bodies in section so not possible to obtain further } \\
\text { details }\end{array}$ \\
\hline
\end{tabular}


double burial at Faughart Lower 116 also appeared to have been laid out in a very deliberate and particular manner (Bowen and Dawkes 2011, plate 54). Sk 1395A (young adult) lay on his left side and was angled towards the body of Sk 1385A (middle-aged); his left arm lay beneath the right arm of the other man. The men's pelves were adjacent to one another and their legs were semi-flexed at the hips by approximately $70^{\circ}$, so that the femora were parallel. ${ }^{2}$ The lower legs of Sk 1395A were flexed at the knees by $120^{\circ}$, while those of Sk $1385 \mathrm{~A}$ were flexed at the knees by $90^{\circ}$. Whoever buried these two men appears to have had the intention of arranging their bodies in the same manner, perhaps as if they were curled up together in sleep (see Murphy 2017, 234-5 for discussion in relation to juvenile burials); the positioning seems very intimate and may be suggestive that a close relationship had existed between the two individuals during life and that this was known by those who had laid them out in their grave. The double burial of the young adult male (Sk 289), who displayed unhealed weapon injuries, with a middle-aged male (Sk 290) from Ballyhanna was also complex (Fig. 2). The right upper arm of Sk 289 overlay the left upper arm of Sk 290 to the elbows which were flexed at $90^{\circ}$ so that the forearms ran in opposite directions. The body of Sk 289 was tilted by approximately $45^{\circ}$ towards the left side away from $\mathrm{Sk}$ 290 but the individuals touched at the pelves. The upper legs of Sk 290 were semi-flexed at the hips (R 10 $0^{\circ}$ L 20 $)$ and knees $\left(\mathrm{R} 60^{\circ} ; \mathrm{L} 50^{\circ}\right)$ toward the right, while the left leg of Sk 289 was extended and the right leg was semiflexed at the hip by $40^{\circ}$ and at the knee by $40^{\circ}$ towards the left side. The lower legs of Sk 290 overlay the right lower leg of Sk 289 and the feet of Sk 290 overlay the left foot of Sk 289. The two bodies were definitely interconnected but the fact the body of the younger man was tilted away from that of the older man and that both individuals' legs were angled away from one another is interesting. This is a different positioning to the more intimate, fully connected lay out apparent in the double burial from Faughart Lower 116 and it could perhaps suggest that the personal connection between the two Ballyhanna men was not as close.

\section{Burials Containing Children Only}

A lot of variation in terms of age-at-death combinations was evident amongst the ten contemporary double burials which contained juveniles only (Table 4). Two sets of full term/neonatal babies (Mount Gamble Sk CXVII and CXVIII, O'Donovan and Geber 2010,
233; Parknahown 5 Sk 1025 and Sk 1026, O’Neill 2009, 181-2) may well have been twins who died around the time of delivery. Even in the modern world twins form a high proportion of prenatal and perinatal deaths (Piontelli 2002, 22) so their discovery in the archaeological record should not be unexpected.

The remainder of the juvenile-only burials comprised a pair of younger children, three burials which contained a young child with an older child, three sets of older children and one burial in which an older child had been buried with an adolescent (see Table 4). These children could have died because of misadventure or disease; they may well have had familial relations or were perhaps just friends within an extended kin group. Early Irish law tracts contain much information about the rights of a child of 'freeman grade and higher' and the responsibilities of those - both biological and foster parents - who were in charge of their wellbeing (Ní Chonaill forthcoming, 7). These documents include warnings against non-intentional injuries, such as those caused by straying animals. Injuries considered to have been avoidable comprise those caused by a child falling from a height, falling into water, or getting injured because of objects such as spikes, spears or stones. If a child suffered from the latter form of injury their carers could be accused of neglect and be required to pay a fine (Ní Chonaill 1997, 30). These records provide us with insights about the hazards of the Irish Medieval environment for children and it seems perfectly feasible that some of the children present in these contemporary multiple burials died as a result of accidents. Accounts contained within Medieval English coroners' rolls illustrate just how fragile life could be and recount details of simple accidents that resulted in the death of two children in a single incident. In one case a pair of twins, John and Joann, were sitting by the fire in their house when a tripod holding a cauldron of hot water broke scalding both children and causing their deaths, while on another occasion a four-week-old baby and his sixteen-week-old niece were both killed when the house in which they lay was burned down. In July 1348 two boys (aged eight and twelve years) were drowned when looking for eels in the Humber, while two boys attending a wake in Bedfordshire went outside to play, fell into a pit and drowned (Hanawalt 1986, 40, 92, 158, 241). One can imagine that it would have been highly appropriate in these cases for the children to have shared a grave. Indeed, a modern tragedy that grabbed newspaper headlines in 2008 involved the death of two young brothers, aged eight and ten years, in a car accident; the two boys were buried within a double coffin 
Table 4: Summary of the demographic and main burial characteristics evident in contemporary double burials that contained only juveniles. All bodies were lying in an extended supine position with the head in a westerly direction unless stated otherwise (see Sprague 2005, 86-9 for method of recording angles).

\begin{tabular}{|c|c|c|c|}
\hline Site & Context & Age-at-death & Physical relationship between individuals \\
\hline Camlin 3 & $\begin{array}{l}\text { Sk } 34 \\
\text { Sk } 35\end{array}$ & $\begin{array}{l}8-11 \text { years } \\
7-11 \text { years }\end{array}$ & $\begin{array}{l}\text { Partly stone-lined grave } \\
\text { Poorly preserved skeletons but upper bodies would have been in contact with one another }\end{array}$ \\
\hline Carrowkeel & $\begin{array}{l}\text { Sk } 85 \\
\text { Sk } 86\end{array}$ & $\begin{array}{l}7-9 \text { years } \\
1-2 \text { years }\end{array}$ & No image available so not possible to assess \\
\hline Claristown 2 & Sk 12 & $\begin{array}{l}12-15 \text { years } \\
10-13 \text { years }\end{array}$ & $\begin{array}{l}\text { Deliberate face-to-face position } \\
\text { Sk } 13 \text { lay in an extended supine position but } S k 12 \text { had legs semi-flexed to the } L \text { at the hips } \\
\text { by } 20^{\circ} \text { and at the knees by } 30^{\circ} \\
\text { Flexion of the legs of } S k 12 \text { made bodies the same length and arrangement symmetrical } \\
\text { No overlap of adjacent arms }\end{array}$ \\
\hline \multirow[t]{3}{*}{ Johnstown 1} & $\begin{array}{l}\text { Sk } 252 \\
\text { Sk } 253\end{array}$ & $\begin{array}{l}5-6 \text { years } \\
3-4 \text { years }\end{array}$ & $\begin{array}{l}\text { L upper arm of Sk } 252 \text { overlay R upper arm of Sk } 253 \\
\text { Possibly touching at feet }\end{array}$ \\
\hline & $\begin{array}{l}\text { Sk } 431 \\
\text { Sk } 433\end{array}$ & $\begin{array}{l}10-12 \text { years } \\
6-8 \text { years }\end{array}$ & $\begin{array}{l}R \text { upper arm of Sk } 433 \text { overlay L upper arm of Sk } 431 \\
\text { Notable gap }(c .10-20 \mathrm{~cm}) \text { between remainder of body so arm overlap seems intentional }\end{array}$ \\
\hline & $\begin{array}{l}\text { Sk } 469 \\
\text { Sk } 470\end{array}$ & $\begin{array}{l}7-9 \text { years } \\
4-5 \text { years }\end{array}$ & $\begin{array}{l}\text { R upper arm of Sk } 470 \text { overlay L upper arm of Sk } 469 \\
\text { Space between R upper arm of Sk } 470 \text { and the torso so overlap seems intentional. Possible } \\
\text { that the arms were interlinked rather than overlapped. }\end{array}$ \\
\hline Killeany 1 & $\begin{array}{l}\text { Sk } 101 \\
\text { Sk } 125\end{array}$ & $\begin{array}{l}8 \text { years } \\
6-9 \text { years }\end{array}$ & $\begin{array}{l}\text { Only physical contact between two individuals occurs at skulls but this seems to be due to } \\
\text { post-mortem movement of skull of one individual posteriorly } \\
\text { Gap of c. } 10 \mathrm{~cm} \text { between bodies } \\
\text { Bodies not preserved from the waist down }\end{array}$ \\
\hline Mount Gamble & $\begin{array}{l}\text { Sk CXVII } \\
\text { Sk CXVIII }\end{array}$ & $\begin{array}{l}37 \text { gestational weeks } \\
37 \text { gestational weeks }\end{array}$ & $\begin{array}{l}\text { R arm of Sk CXVII described as overlying the ribs of Sk CXVIII } \\
\text { Both infants had distinctive positions of } L \text { arms which were flexed at the elbows to enable } \\
\text { positioning of the } L \text { hand on the R shoulder }\end{array}$ \\
\hline \multirow[t]{2}{*}{ Parknahown 5} & $\begin{array}{l}\text { Sk } 1025 \\
\text { Sk } 1026\end{array}$ & $\begin{array}{l}\text { 42-44 gestational weeks } \\
40-42 \text { gestational weeks }\end{array}$ & $\begin{array}{l}\text { L upper arm of Sk } 1025 \text { lay parallel to R upper arm of Sk 1026. L forearm of Sk } 1025 \text { overlay } \\
\text { R forearm of Sk } 1026 \\
\text { Hands not preserved }\end{array}$ \\
\hline & $\begin{array}{l}\text { Sk } 121 \\
\text { Sk } 123\end{array}$ & $\begin{array}{l}2.5-5.5 \mathrm{yrs} \\
7.5-9.5 \mathrm{yrs}\end{array}$ & $\begin{array}{l}\text { Both individuals had 'ear muff' stones at either side of head } \\
\mathrm{R} \text { forearm of Sk } 121 \text { possibly overlapped L forearm of Sk 123. If not overlap, definite contact } \\
\text { between forearms as well as pelves }\end{array}$ \\
\hline
\end{tabular}

(Daily Mail Reporter 2008). It is, of course, possible that some of the children in the juvenile-only pairings had died as a consequence of infectious disease although one might anticipate that greater numbers of individuals would have been caught up in any such epidemic.

As was the case with the adult-only contemporary burials, those with pairings of juveniles were arranged so that the bodies lay parallel to one another with the heads generally level in a manner that conformed to typical Christian burial practices. It was possible to examine the body positioning of the individuals in eight of the ten cases and, as was the case for the adult-only burials, overlapping of the adjacent arms was a prominent feature in the juvenile-only contemporary burials and this configuration was evident in five of the pairings (see Table 4). In addition, the right arm of one of the full term/neonatal possible twins at Mount Gamble (Sk CXVII) was described as overlying the ribs of the other baby (Sk CXVIII) and both infants had distinctive positions of their left arms which were 


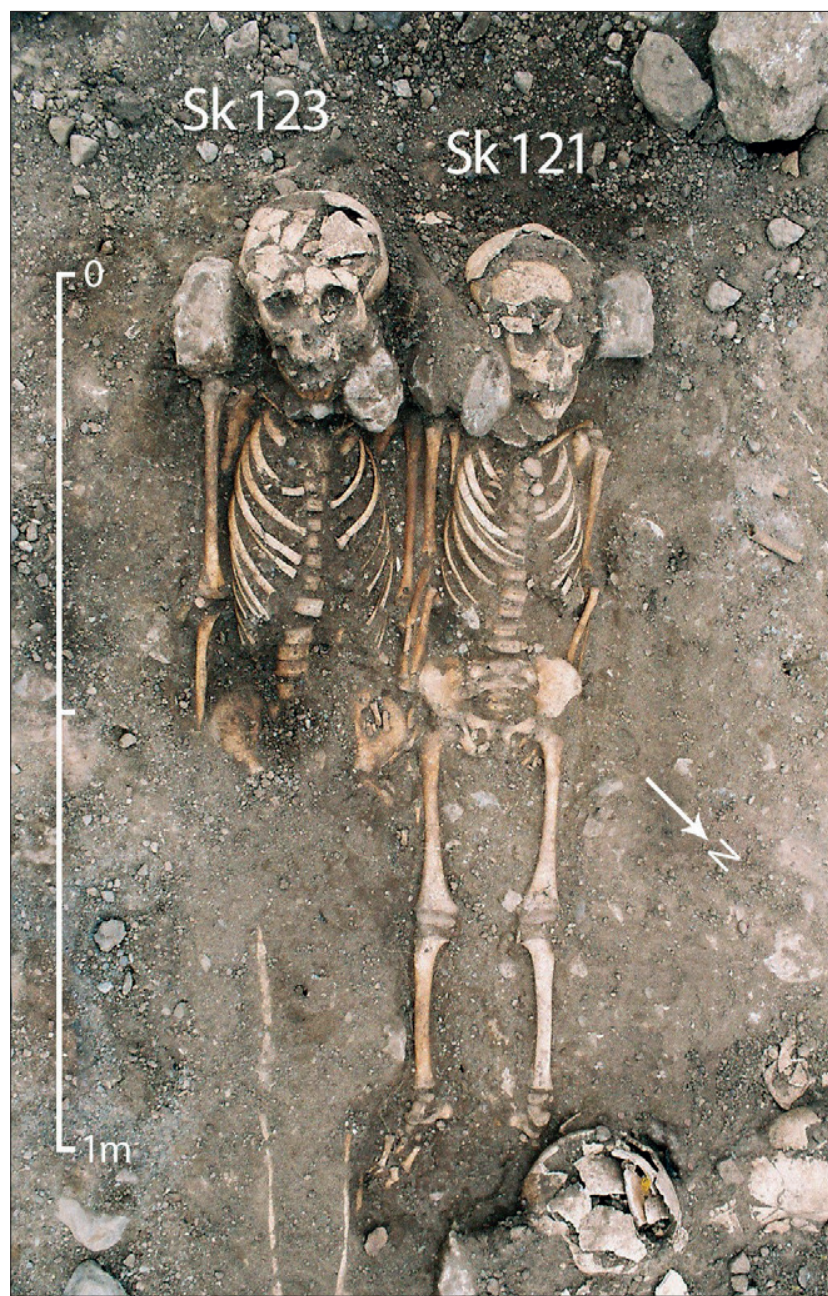

Figure 3: Contemporary double burial of two juveniles (Sk 121; 2.5-5.5 years and Sk 123; 7.5-9.5 years), both of whom were associated with 'ear muff' stones, from Parknahown 5, Co. Laois (Photo by Archaeology Consultancy Services Unit, annotation by Libby Mulqueeny).

flexed at the elbows to enable the positioning of the hand on the right shoulder (O'Donovan 2005, 95). In the burial of Sk 121 (older child) and Sk 123 (younger child) at Parknahown 5 the heads of both children had been supported with 'ear muff' stones (O'Neill 2009, 205-6, plate 56) (Fig. 3). The reason for the use of 'ear muff' stones is poorly understood but it is thought they may have been used to prevent movement of the head, thereby ensuring the deceased was positioned facing eastward towards the Risen Christ on Judgement Day (Daniell 1997, 180-1).

The pair buried together at Claristown 2 were considered to have been deliberately buried in a way that meant they were facing one another (Russell 2004, fig. 16). It is difficult to verify the direction in which the heads would have originally faced (see Duday 2009, 17-19), but the fact the bodies were so well aligned and evenly positioned, with the frontals practically touching, is suggestive this was intentional. The plan for Skeleton 13 (10-13 years) is indicative that the younger of the two individuals was buried in an extended supine position but Skeleton 12 (12-15 years) had legs that were semi-flexed to the left at the hips by $20^{\circ}$ and at the knees by $30^{\circ}$. As such, it would seem that the older of the individuals had deliberately been positioned in a way so that the body was angled towards the younger, making a face-to-face position all the more feasible. The flexion of the legs of the older individual also meant the two bodies extended for the same length in the grave cut, even though there was space to spare, so this symmetry of length may have been important to those who interred the two children.

As was evident for the adult-only contemporary burials, there seems to have been a desire to physically connect the bodies of children buried together in such graves; the presence of additional space in several of the graves suggests this cannot always be explained as a practical measure to ensure that both bodies fitted within the grave pit. It is interesting to note that the bodies of a juvenile pair were only kept physically apart in one case, at Kileany 1 (Sk 101 and Sk 125, Wiggins and Kane 2009b, 146, plate 23). While the skulls of these two older children touched one-another this appears to have occurred during decomposition when the skull of Sk 125 had moved posteriorly. The occurrence of close physical contact in the majority of burials $(7 / 8)$ could be viewed as suggestive that most of the deceased children had close relationships during life that those who interred them wished to reflect in the layout of their shared grave.

\section{Burials Containing Adults and Children}

Half $(50.0 \% ; 21 / 42)$ of the contemporary multiple burials comprised an adult and a child and can therefore provide concrete evidence of the entwined worlds of children and adults in Medieval Irish society. It was possible to determine adult age-at-death in twenty of the contemporary multiple burials; $45.0 \%(9 / 20)$ were young adults, while $55.0 \%(11 / 20)$ were middle-aged or older adults. The only details currently available for the double burial at Drumkay Glebe was that it comprised the remains of an adult and an infant (O'Donovan 2014, 197). Adult age-at-death and sex were determinable in seventeen of the adult-juvenile contemporary burials, ten of which included adult males (58.8\%; 10/17), while the adult was female in seven cases $(41.2 \%$; $7 / 17)$. In the following sections the different demographic 
Table 5: Summary of the demographic and main burial characteristics evident in contemporary double burials that contained the remains of an adolescent with an adult male. All bodies were lying in an extended supine position with the head in a westerly direction unless stated otherwise (see Sprague 2005, 86-9 for method of recording angles).

\begin{tabular}{|c|c|c|c|c|}
\hline Site & Context & $\begin{array}{c}\text { Age-at-death } \\
\text { (years) }\end{array}$ & Sex & Physical relationship between individuals \\
\hline \multirow[t]{2}{*}{ Ballykilmore 6} & $\begin{array}{l}\text { Sk } 698 \\
\text { Sk } 699\end{array}$ & $\begin{array}{l}35-50 \\
14-16\end{array}$ & $\begin{array}{l}\text { Male } \\
\text { Male }\end{array}$ & $\begin{array}{l}\text { L forearm of Sk } 698 \text { touched R forearm of Sk } 699 \text { but did not overlap } \\
\text { Legs of both individuals were angled at hips by c. } 30-40^{\circ} \text { but ran parallel to one } \\
\text { another }\end{array}$ \\
\hline & $\begin{array}{l}\text { Sk } 399 \\
\text { Sk } 415\end{array}$ & $\begin{array}{l}18-35 \\
13-14\end{array}$ & $\begin{array}{l}\text { Male } \\
\text { Male }\end{array}$ & $\begin{array}{l}\text { Upper body of Sk } 415 \text { was slightly angled towards the R, while that of Sk } 399 \text { was } \\
\text { supine } \\
\text { Pelves adjacent while heads at different levels. L upper arm and thorax of Sk } 415 \\
\text { overlay the R arm of Sk } 399 \\
\text { In Sk } 415 \text { the L leg was semi-flexed at the hip by } 60^{\circ} \text {, while the R leg was semi- } \\
\text { flexed at the hip by } 30^{\circ} .90^{\circ} \text { flexion at the knees and the ankles lay beneath the } \\
\text { adjacent R lower leg of Sk } 399 \\
\text { The legs lay slightly apart in } S k 399 \text { with the L leg semi-flexed at the hip by } 15^{\circ} \text { and } \\
\text { extended at the knee and the R leg semi-flexed at the hip by } 30^{\circ} \text { and at the knee by } \\
45^{\circ}\end{array}$ \\
\hline Claristown 2 & $\begin{array}{l}\text { Sk } 5 \\
\text { Sk } 6\end{array}$ & $\begin{array}{l}18-35 \\
16-17\end{array}$ & $\begin{array}{l}\text { Male } \\
\text { Male }\end{array}$ & $\begin{array}{l}R \text { arm of } S k 5 \text { overlapped } L \text { arm of } S k 6 \text { at the elbows } \\
L \text { foot of } S k 6 \text { overlapped } R \text { foot of } S k 5\end{array}$ \\
\hline Collierstown 1 & $\begin{array}{l}\text { Sk } 54 \\
\text { Sk } 55\end{array}$ & $\begin{array}{l}14-17 \\
18-35\end{array}$ & $\begin{array}{l}\text { Indeterminate } \\
\text { Male }\end{array}$ & $\begin{array}{l}\text { Grave displayed wooden lining } \\
L \text { arm of } S k 54 \text { overlay } R \text { arm of } S k 55 \text { at the elbows }\end{array}$ \\
\hline
\end{tabular}

Table 6: Summary of the demographic and main burial characteristics evident in contemporary double burials that contained the remains of a young adult with a juvenile. All bodies were lying in an extended supine position with the head in a westerly direction unless stated otherwise (see Sprague 2005, 86-9 for method of recording angles).

\begin{tabular}{|c|c|c|c|c|}
\hline Site & Context & Age-at-death & Adult sex & Physical relationship between individuals \\
\hline Ardsallagh 1 & $\begin{array}{l}\text { Sk } 24 \\
\text { Sk } 26\end{array}$ & $\begin{array}{l}18-35 \text { years } \\
7-10 \text { years }\end{array}$ & Male & $\begin{array}{l}\text { Skull of Sk } 26 \text { positioned adjacent to the L elbow of Sk } 26 \\
L \text { pelvis and leg of Sk } 24 \text { overlay the R side of Sk } 26 \\
\text { R leg of Sk } 24 \text { angled at hip by } 150 \text { and extended with lower leg overlying R lower leg } \\
\text { of Sk } 26\end{array}$ \\
\hline Ballyhanna & $\begin{array}{l}\text { Sk } 824 \\
\text { Sk } 823\end{array}$ & $\begin{array}{l}18-35 \text { years } \\
6-8 \text { months }\end{array}$ & Male & $\begin{array}{l}\text { Sk } 823 \text { lay in an extended supine position on the chest and abdomen of Sk } 824 \\
\text { Sk } 823 \text { lay on the same axis as Sk } 824\end{array}$ \\
\hline Baysrath & $\begin{array}{l}\text { Sk } 2274 \\
\text { Sk } 2291\end{array}$ & $\begin{array}{l}18-35 \text { years } \\
6-11 \text { yrs }\end{array}$ & Indeterminate & Poorly preserved individuals. Details not provided \\
\hline Treanbaun & $\begin{array}{l}\text { Sk } 27 \\
\text { Sk } 30\end{array}$ & $\begin{array}{l}\text { c. } 10-14 \text { years } \\
18-35 \text { years }\end{array}$ & Indeterminate & $\begin{array}{l}\text { Sk } 27 \text { is poorly preserved. Head of Sk } 27 \text { lay adjacent to the L elbow of Sk } 30 \\
\text { R side of torso of Sk } 27 \text { partly overlay L side of torso of Sk } 30 \\
R \text { side of pelvis of } S k 27 \text { partly overlay } L \text { femur of } S k 30 \\
\text { The feet of the individuals lay adjacent to one another }\end{array}$ \\
\hline
\end{tabular}

combinations will be examined to see if they can yield insights about the nature of the interactions between adults and children in Irish Medieval society.

\section{Death Due to Childbirth}

Among the seven burials of one or more juvenile with an adult female, two involved the burial of newborn infants with young adult females and presumably these represent the deaths of mothers and babies in the aftermath of childbirth. A neonate from Parknahown 5 (Sk
004) had been placed in an extended supine position, with the head to the west, lying on the left arm and chest of a young woman (Sk 003) (O'Neill 2009, 234). Unfortunately, the physical relationship between the young woman and neonate buried together at Bettystown, Co. Meath, is not known.

\section{Adolescents - The Transition to Adulthood}

Three of the five younger adults were buried with adolescents and a further adolescent male had been buried 
with a middle-aged man at Ballykilmore 6 (Table 5). In all four of the adult male and adolescent burials complementary funerary rituals reflective of Christian practice were evident; the bodies were generally in an extended supine position with the heads adjacent to one another and orientated in a westerly direction. The overlapping arms evident in many of the adult-only and juvenile-only burials (see above) were visible in two of the four burials, while the forearms touched but did not overlap in the burial of a middle-aged male (Sk 698) and adolescent boy (Sk 699) from Ballykilmore 6 (Channing 2009, plate 30).

The positioning of a young adult male (Sk 399) and an adolescent male ( $\mathrm{Sk} 415$; aged 13-14 years) with weapon trauma from Ballykilmore 6 (Channing 2014, fig. 3.14) is reminiscent of that evident in the double burial of two adult males from Faughart Lower 116 (Sk 1385A and Sk 1395A), also with fatal weapon injuries (see Table 2). The upper body of the adolescent was slightly angled towards the right, while that of the adult was supine. The pelvis appears to have been the focal point of the arrangement since the heads were not even; the left upper arm and thorax of Sk 415 overlay the adjacent arm of Sk 399, while the legs of both individuals displayed flexion. In the case of Sk 415 the left leg was semi-flexed at the hip by $60^{\circ}$, while the right leg was semi-flexed at the hip by $30^{\circ}$; flexion at the knees of $90^{\circ}$ was evident and the ankles lay beneath the adjacent right lower leg of Sk 399. The adult's legs lay slightly apart with the left leg semi-flexed at the hip by $15^{\circ}$ and extended at the knee and the right leg semi-flexed at the hip by $30^{\circ}$ and at the knee by $45^{\circ}$. As was the case for the burials from Faughart Lower 116, this would seem to be a very deliberate and intimate positioning and it is possible that these two individuals had a close relationship in life that those who interred them wanted to portray through the manner in which the bodies were laid out in the grave.

The Irish law tracts indicate that a child's legal status changed at the age of twelve years. Up until this age legal punishments involved general chastisement and the withholding of food, whereas individuals aged 12-17 years moved closer to the realm of adulthood and they were considered mature enough to be able to make amends for their crimes through compensation and restitution, thereby restoring social harmony (Ní Chonaill forthcoming, 15). In addition, the law tracts make specific reference to the status of male freemen aged 14-20 years and a youth who occupied temporary dwellings on his father's land was referred to as a fer midboth (man of middle huts). Such individuals aged 14-17 years had a lower honour price than those aged 17-20 years, who could also be more prosperous and have more rights (Kelly 1988, 82). Support for the inclusion of adolescents in the world of adults, can be found in a contemporary double grave at Ballykilmore 6 that contained the remains of a 13-14-year-old adolescent male (Sk 415) and a young adult male (Sk 399), both of whom displayed weapon injuries consistent with attempted decapitation (Channing 2014, 33; RandolphQuinney 2009, 64-5; see Table 2). We can imagine that adolescent boys and men would have worked together in groups which undertook the most physical - and potentially dangerous - day-to-day tasks in a community (see Kelly 1988, 149-51 for details of such accidents) and it is probably not entirely surprising that this demographic combination is well represented in contemporary multiple burials. Indeed, three of the four adolescents were identified as males, while the sex of the adolescent from Collierstown 1 was not determined.

\section{The Older and the Younger}

It seems possible to explain the simultaneous burials of the two women and newborn babies and the four adolescent-adult male burials for the reasons discussed above. The majority of the remaining adult-juvenile contemporary burials comprise those of older individuals with children of a variety of ages - five middle-aged females, three middle-aged and one elderly male, and a middle-aged/older adult of indeterminable sex (10/14), with only two young adult males and two young adults of indeterminable sex (4/14).

The four young adult and juvenile burials comprised those of two young adult males from Ardsallagh 1 and Ballyhanna and two poorly preserved burials of young adults of indeterminate sex from Baysrath and Treanbaun (Table 6). Details of the burial context are not available for the pair from Baysrath (Channing 2012, 173), but the three burials for which context details are available indicate that general Christian burial practices had been followed - an extended supine body position with the head in a westerly direction. Sk 24 from Ardsallagh 1 was interred with Sk 26, a 7-10-yearold juvenile, whose skull was positioned adjacent to the adult's left elbow; the left side of the adult's skeleton overlay the adjacent area of the juvenile's body and it is probable the juvenile had been placed first into the grave. The interment of the juvenile before the adult seems unusual and it is possible there was a degree of expediency associated with the burial of the adult 


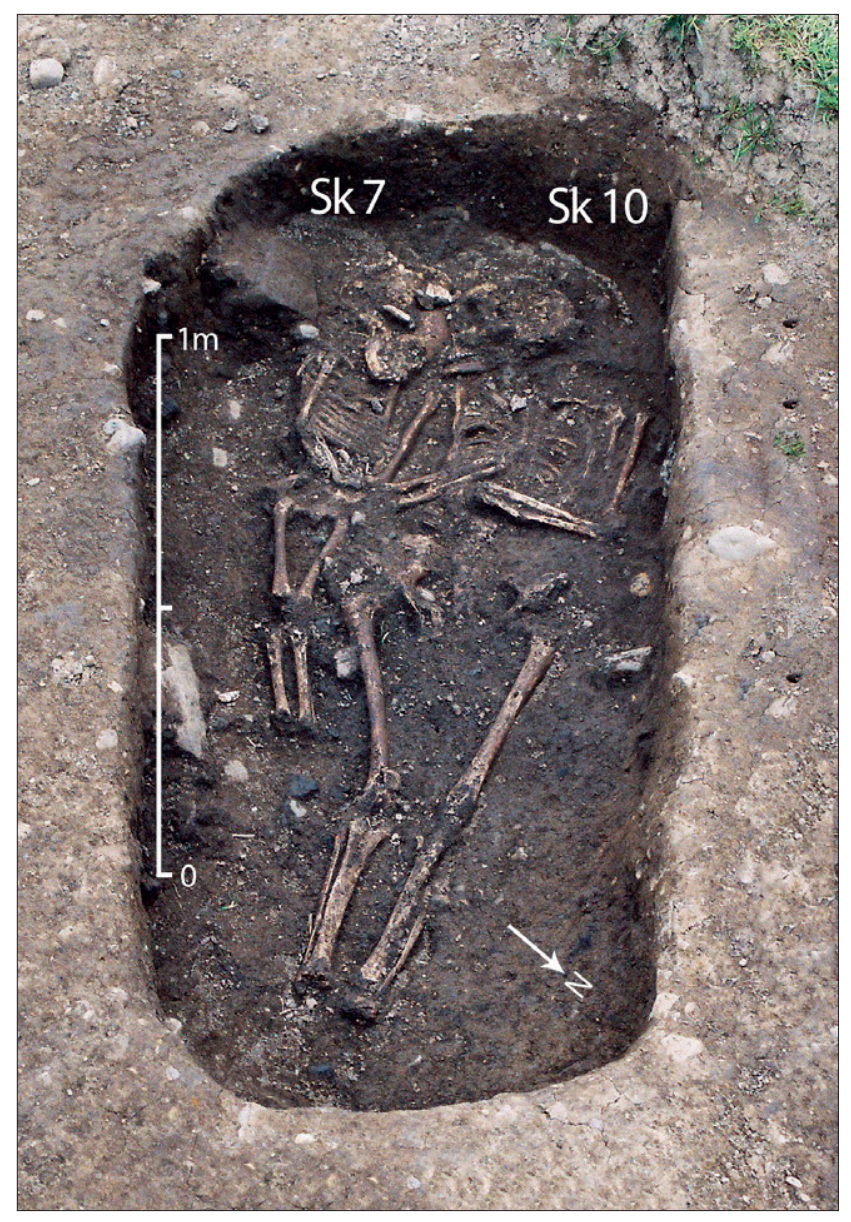

Figure 4: Contemporary double burial of a woman (Sk 10; 35-50 years) and child (Sk 7; seven years) from Ardsallagh 1, Co. Meath (Photo by Archaeology Consultancy Services Unit, annotation by Libby Mulqueeny).

who may have been interred after a short interval had elapsed following the burial of the juvenile. The overlap seems unnecessary for practical reasons, however, since space of around $20-50 \mathrm{~cm}$ was present between the right side of the adult and the wall of the grave cut (Clarke and Carlin 2008a, plate 21). It is therefore possible that those who interred the bodies were attempting to physically connect the remains of the two individuals but without wanting to disturb the body of the child. The position of the pair in the double burial at Treanbaun was similar and the head of an older child/ younger adolescent ( $\mathrm{Sk} 27$ ) lay adjacent to the left elbow of the adult (Sk 30). In this case, however, the right side of the torso and pelvis of the juvenile overlay the adjacent left side of the body of the adult (Muñiz Pérez 2009, plate 46). Sk 824 from Ballyhanna was buried with Sk 823, an infant of 6-8 months, who had been suffering from active rickets at death. The infant was positioned lying in an extended supine position on the chest and abdomen of the adult (McKenzie and Murphy 2018, 66).
Turning to the burials of the middle-aged and older adults with juveniles it was also the case that typical Christian burial practices were evident in all of those for which details of the burial context were available (Table 7). Two infants buried with a middle-aged female and male respectively had both been laid on the arm of the adult along the same axis as the older individual. In a poorly preserved pair of a middle-aged/ older adult and an infant from Baysrath the infant appeared to have lain adjacent to the left knee of the adult (Channing 2012, 172). While placement on the arm and within the physical space of the adult body is suggestive of a degree of protection and intimacy, the location at the lower leg in this case may be suggestive that a weaker relationship had existed between the two individuals (although see below).

The heads were positioned adjacent, or almost adjacent, to one another in all six of the burials that contained the remains of younger or older children and a middle-aged/older adult (Fig. 4). The heads of both the middle-aged woman (Sk 795) and the older child (Sk 797) in the burial at Parknahown 5 were associated with 'ear muff' stones (O'Neill 2009, 178) (Fig. 5). In each case contact between the adjacent arms of the two individuals was evident; in two cases the nature of the contact appeared particularly intentional. In the burial of the middle-aged woman (Sk 85) and the young child (Sk 115) at Johnstown 1 the right upper arm of the child overlay that of the adult, while the right arm of the adult was flexed at the elbow by $90^{\circ}$ and lay across her abdomen so that her hand rested on the right elbow of Sk 115 (Fibiger 2008, plate 15). In the burial of the middle-aged man (Sk 94) and the older child (Sk 98) from Camlin 3 the left side of the body of the child overlay the adjacent right side of the adult (Flynn 2011, fig. 6). In the Early Anglo-Saxon English burials, it was generally found that the child was afforded differential burial rites to that of the associated adult. Indeed, at one burial at Edix Hill, Cambridgeshire, a perinatal infant had been placed like a pillow beneath the head of a wealthy adult female with multiple pathologies. This and other similar findings led Crawford (2007, 88-90) to conclude that the bodies of children, in at least a proportion of the contemporary multiple burials, were being viewed as valuable objects and that it was the adults who had the dominant social identity within such burials. The situation for Medieval Ireland again differs in that the adults and children within the contemporary multiple burials all appear to have both been afforded typical Christian burial rites. There is no evidence to suggest that the social identity of the 


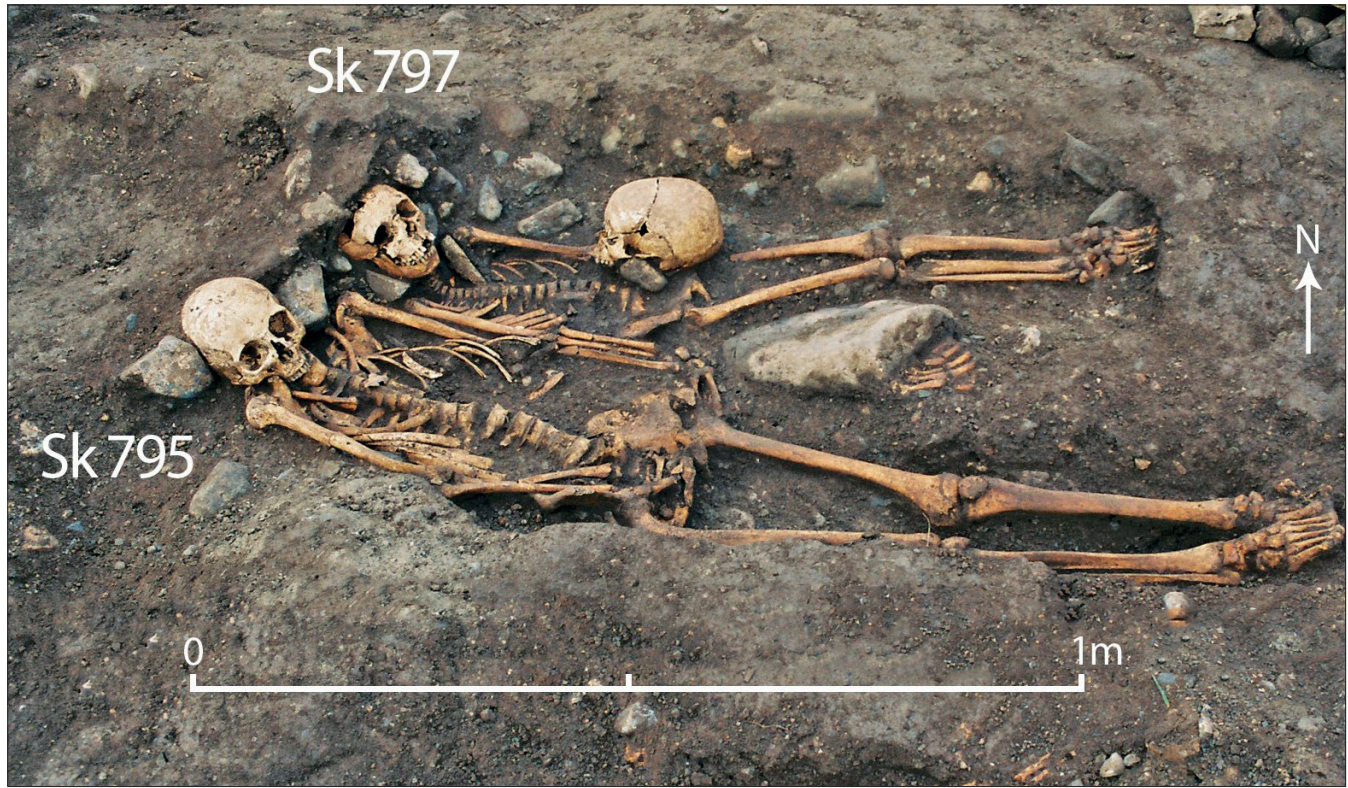

Figure 5: Contemporary double burial of a woman (Sk 795; 35-50 years) and child (Sk 797; 9-14 years), both of whom were associated with 'ear muff' stones, from Parknahown 5, Co. Laois (Photo by Archaeology Consultancy Services Unit, annotation by Libby Mulqueeny).

adult was in any way dominant to that of the associated child.

The burial of young adults with children could perhaps represent the interment of a parent and child although they could equally represent other relationships or indeed have had no biological relationship. When it comes to the interment of middle-aged or older adults and juveniles if they were biological relatives they are unlikely to have been siblings. Returning to the modern burial of a grandfather and grandchild that was the inspiration for this study, it is possible that some of these pairings could represent the remains of a grandparent and grandchild, particularly in the two cases where the physical connection in the grave seemed to be particularly intimate. Indeed, a late twelfth-century account from England contained within the Life of St. Peter of Cornwall and Launceston describes the burial of a grandfather with his infant granddaughter. When the funeral procession of this holy man was making its way to the church the body of his granddaughter who had 'died in a state of innocence, immediately after her baptism, and still dressed in white' was brought out of her house and placed in her grandfather's coffin lying on his knees (Hull and Sharpe 1985, 27 as quoted in Crawford 2007, 86). When attempting to find potential generational relationships between the adults and children in the double burials it is also important to remember the impact that fosterage may have had on households. Everyone of freeman status and higher was eligible to participate in fosterage (see Ní Chonaill 1997), although it seems likely that not all members of the lower freeman classes would have done so. Nevertheless, there remains the possibility that some of the pairings represent the simultaneous burial of individuals related through fosterage. The law tracts indicate that the foster child was to be fully integrated into the foster-family and strong bonds could be formed for life; one thirteenth-century poem describes the anguish felt by a foster-mother upon the death from disease of her foster-daughter Gormlaith, a young noble girl who died before the age of five years (Ní Chonaill forthcoming, 25).

While the middle-age category may seem young by today's standards for grandparents it is important to consider the cultural context from which these burials derived. The Irish law tracts indicate that a girl could marry once her fosterage was complete - at either the age of fourteen or seventeen years depending on the text consulted (Kelly 1988, 88). If people could get married at this young age they could well have been grandparents by the time they reached their mid to late thirties, and certainly by their forties or fifties (see Appleby, this volume). Age is a relative concept and in his study of old age in Late Medieval England Rosenthal (1996, 1) cautioned that: '... the iron law of aging is better presented by the historian with some relativity; a sliding scale, if we will, on which all who survive are gauged, though at different times and along different scales of evaluation'. Chamberlain (2006, 53, 90) has discussed the life spans of populations in Medieval Europe and concluded that people would have had the potential to live into their seventies. It is generally found in Medieval skeletal populations, however, that the majority of adults died in their twenties, thirties or forties and this was the case for all of the more substantial populations included in the current study. This profile does 
Table 7: Summary of the demographic and main burial characteristics evident in contemporary double burials that contained the remains of a middle-aged or older adult with a juvenile. All bodies were lying in an extended supine position with the head in a westerly direction unless stated otherwise (see Sprague 2005, 86-9 for method of recording angles).

\begin{tabular}{|c|c|c|c|}
\hline Site & Context & Age-at-death & Physical relationship between individuals \\
\hline \multicolumn{4}{|c|}{ Mature women and juveniles } \\
\hline Ardsallagh 1 & $\begin{array}{l}\text { Sk } 7 \\
\text { Sk } 10\end{array}$ & $\begin{array}{l}7 \text { years } \\
35-50 \text { years }\end{array}$ & $\begin{array}{l}\text { Heads adjacent to one another } \\
\text { Upper body of Sk } 7 \text { angled towards Sk } 10 \text { by c. } 30^{\circ} \\
\text { R elbow of Sk } 10 \text { touched L forearm of Sk } 7\end{array}$ \\
\hline Bettystown & $\begin{array}{l}\text { Context not stated } \\
\text { Context not stated }\end{array}$ & $\begin{array}{l}35-50 \text { years } \\
0-1 \text { years }\end{array}$ & Details not available \\
\hline Johnstown 1 & $\begin{array}{l}\text { Sk } 85 \\
\text { Sk } 115\end{array}$ & $\begin{array}{l}35-50 \text { years } \\
4-5 \text { years }\end{array}$ & $\begin{array}{l}\text { Heads adjacent to one another } \\
\text { R upper arm of Sk } 115 \text { overlay that of Sk } 85 \text { with the L elbow of Sk } 85 \text { touching the L pelvis of } \\
\text { Sk } 115 \\
\text { R arm of Sk } 85 \text { flexed at the elbow at } 90^{\circ} \text { so it lay across abdomen and the hand rested on the } \\
\text { R elbow of } S k 115 \\
\text { L pelvis of Sk } 85 \text { touched R upper leg of Sk } 115\end{array}$ \\
\hline Parknahown 5 & $\begin{array}{l}\text { Sk } 795 \\
\text { Sk } 797\end{array}$ & $\begin{array}{l}35-50 \text { years } \\
9-14 \text { years }\end{array}$ & $\begin{array}{l}\text { Heads adjacent to one another and both have 'ear muff' supports } \\
\mathrm{R} \text { arm of Sk } 797 \text { was extended and ran parallel to L arm of Sk } 795 \text { which was also extended. } \\
\text { Adjacent forearms touched and the hands would have been located adjacent to one another. } \\
\text { These are not preserved so not possible to establish if connected } \\
\text { Large stone located adjacent to the upper legs of both individuals which has resulted in their } \\
\text { legs angled away from one another }\end{array}$ \\
\hline Raystown & $\begin{array}{l}\text { Sk } 852 \\
\text { Sk } 853\end{array}$ & $\begin{array}{l}3.5-4.5 \text { years } \\
35-50 \text { years }\end{array}$ & $\begin{array}{l}\text { Vertex of head of Sk } 852 \text { positioned c. } 10 \mathrm{~cm} \text { lower to that of Sk } 853 \\
\text { R upper arm of Sk } 853 \text { was extended and ran parallel to L upper arm of Sk } 852 \text {. The } L \text { arm of Sk } \\
852 \text { was tightly flexed at the elbow by } 170^{\circ} \text { with the hand positioned towards the } L \text { shoulder. The } \\
\text { R elbow of Sk } 853 \text { touched the } L \text { elbow of Sk } 852 \\
\text { The extended R lower arm of Sk } 853 \text { was rotated so that the palmar surface of the R hand lay } \\
\text { on the ground and the fifth finger touched the L femur of Sk } 852\end{array}$ \\
\hline \multicolumn{4}{|c|}{ Mature men and juveniles } \\
\hline Ardsallagh 1 & $\begin{array}{l}\text { Sk } 11 \\
\text { Sk } 15\end{array}$ & $\begin{array}{l}50+\text { years } \\
10-11 \text { years }\end{array}$ & $\begin{array}{l}\text { Heads adjacent to one another } \\
\text { R upper arm of Sk } 11 \text { lay adjacent to L upper arm of Sk } 15 \text { and possibly touched. Not possible to } \\
\text { observe positioning of lower arms due to poor preservation } \\
\text { Pelves and lower limbs did not touch }\end{array}$ \\
\hline Ballyhanna & $\begin{array}{l}\text { Sk } 876 \\
\text { Sk } 877\end{array}$ & $\begin{array}{l}35-50 \text { years } \\
40-44 \text { gestational } \\
\text { weeks }\end{array}$ & $\begin{array}{l}\text { Sk } 877 \text { lay in an extended supine position on L chest and arm of Sk } 876 \\
\text { Sk } 877 \text { lay on same axis as Sk } 876\end{array}$ \\
\hline Camlin 3 & $\begin{array}{l}\text { Sk } 94 \\
\text { Sk } 98\end{array}$ & $\begin{array}{l}35-50 \text { years } \\
6-10 \text { years }\end{array}$ & $\begin{array}{l}\text { Skull of Sk } 98 \text { has moved post-mortem but its vertex may originally have been approximately } 10 \\
\mathrm{~cm} \text { lower than that of Sk } 94 \text {. Head of Sk } 98 \text { may have lain on R shoulder of Sk } 94 \text { but difficult to } \\
\text { be certain } \\
\text { L upper arm and chest of Sk } 98 \text { overlay R upper arm and possibly chest of Sk } 94 \text {. L lower arm of } \\
\text { Sk } 98 \text { not preserved } \\
\text { L pelvis of Sk } 98 \text { overlay R lower arm of Sk } 94\end{array}$ \\
\hline Parknahown 5 & $\begin{array}{l}\text { Sk } 555 \\
\text { Sk } 567\end{array}$ & $\begin{array}{l}35-50 \text { years } \\
0-6 \text { months }\end{array}$ & $\begin{array}{l}\text { All that remains of Sk } 567 \text { were pelvic and upper leg bones which were found at the L forearm } \\
\text { of Sk } 555 \\
\text { Excavator suggested that Sk } 567 \text { had laid on L arm of Sk } 555 \\
\text { Sk } 567 \text { lay on same axis as Sk } 555\end{array}$ \\
\hline Mature adults & juveniles & & \\
\hline Baysrath & $\begin{array}{l}\text { Sk } 2401 \\
\text { Sk } 2403\end{array}$ & $\begin{array}{l}35-50 / 50+\text { years } \\
0-1 \text { years }\end{array}$ & Poorly preserved individuals. Skull of Sk 2403 lay adjacent to L knee of Sk 2401 \\
\hline
\end{tabular}


not match any model life tables or data generated from historical sources and is considered to occur because of methodological issues which cause osteoarchaeologists to under-age older adults (see Maaranen and Buckberry, this volume). As such, the majority of adults buried simultaneously with children in these burials should be considered to be middle-aged at the very least and representative of the older members of their communities. So how can we explain this pattern?

The variety of ages represented in the juveniles associated with the middle-aged and older adults is suggestive that a variety of factors may have been responsible for the simultaneous deaths. While some may have been related to accidents it is probable that the demographics are also reflective of a natural pattern of attrition. Short periods of famine, adverse climatic conditions, a harsh working environment and exposure to new diseases all tend to produce an elevated attritional pattern of mortality that particularly affects the youngest and oldest members of society (Chamberlain 2006, 69). The Irish Medieval historical sources are full of accounts detailing the occurrences of epidemic diseases as well as poor weather conditions that led to crop failure, the death of livestock and ultimately resulted in famine (Nicholls 1993, 410; Ó Cróinín 2017, 125-6). Only a single individual from these simultaneous burials displayed pathological lesions that are suggestive of notable ill health that probably contributed to their death. This was an infant (Sk 823) in a double burial at Ballyhanna with lesions characteristic of rickets who was buried lying on the chest of a young adult male (Sk 824) (Murphy 2015, 115-17). It needs to be remembered, however, that some of the individuals may have died as a consequence of virulent disease that killed before lesions developed in the skeleton.

As discussed above, the Irish law tracts provide information about the nature of accidents that could befall adults and children (Kelly 1988, 149-51; Ní Chonaill 1997, 30) and we have already noted accounts within the Medieval English coroner's rolls of children getting scalded to death by boiling water or drowning in pits. As such, we know that daily life could have been hazardous (Hanawalt 1986). An important aspect of Irish Medieval social structure was fosterage and it is in the law tracts relating to this practice that we can catch glimpses of how people might encounter such dangers. An important part of the rationale behind fosterage was to educate the child for their role in later life. Girls were taught in matters relating to cooking and the tending of sheep and young livestock, while boys were schooled in farming activities (Ní Chonaill 1997, 29;
Fitzsimons 2001, 141). We can therefore imagine how women and girls might encounter accidents within the domestic environment when undertaking household tasks, while those involving boys and men might take place out on the farm or in the countryside.

The law tracts also provide insights concerning the treatment of older members of society; children were expected to support their parents in old age, with the relationships between a mother and daughter and father and son being particularly highlighted (Dillon 1936, 129-30). Three categories of 'son of a living father' are identified and include a macc té (warm son), who fulfils his filial duties, and a macc úar (cold son) who does not and is ostracised from the family. The filial duty (goire) can also extend to a daughter and involve the care of a mother in her old age (Kelly 1988, 80). These tracts indicate that close connections existed between grown up children and their parents and undoubtedly involved relationships between grandparents and grandchildren.

The burial of a middle-aged male (Sk 876) with a newborn infant (Sk 877) from Ballyhanna finds some resonance with the modern burial that inspired this paper (McKenzie and Murphy 2018, 66). Presumably the mother of the infant survived the birthing process but who was the man with whom the infant was buried? The interment of the baby on top of the man is suggestive of some connection between the two or their families - was the man a grandfather, father or uncle, or were they just members of the same community and it was considered appropriate for the adult body to protect that of the young baby?

\section{Conclusions}

Contemporary multiple burial is a minority burial rite that has been identified in both the Early Anglo-Saxon and Medieval Christian Worlds, although differences in the meaning behind the practice appear to exist. Double burials predominate in both belief systems but their demographics differ; within an Early AngloSaxon context juvenile-only burials occur infrequently and there is evidence to suggest that in cases when the body of a child accompanied that of an adult it was objectified and added value to the adult interment (Stoodley 2002; Crawford 2007).

In the vast majority of the Irish Medieval contemporary burials - regardless of whether they contain the remains of adults-only, juveniles-only or adults with juveniles - the funerary rites tended to be generally uniform, with the bodies lying parallel and the heads 
positioned adjacent to one another and orientated towards the west. In a notable majority of cases where burial details were available physical contact between the remains was evident (91.7\%; 33/36); indeed, it is a lack of connectivity between the individuals that would appear to be atypical. While it could be argued that slight overlapping of the arms occurred for practical reasons to ensure the bodies fitted within the grave-cut the practice appears to have been too frequent for this to be the case and it is considered likely that at least some of those who interred the remains intentionally ensured this degree of physical overlap. Indeed, definitive evidence of the deliberately heightening of the physical connection between two individuals was evident in a number of cases, including the remains of the two adult men from Church Road, Lusk, who were buried holding hands (O'Connell 2014, 180, fig. 11.9); the pair of men from Faughart Lower 116 (Bowen and Dawkes 2011, plate 54) and the man and teenage boy from Ballykilmore 6 (Channing 2014, fig. 3.14) who were buried as if curled up together in sleep; the resting of the hand of one neonatal infant on the chest of the other from Mount Gamble (O'Donovan 2005, 95); the facing pair of juveniles buried together at Claristown 2 (Russell 2004, fig. 16); the touching of the elbow of a young child by the hand of a middle-aged woman at Johnstown 1 (Fibiger 2008, plate 15); and the overlying of the body of an older child on that of a middle-aged man in a burial at Camlin 3 (Flynn 2011, fig. 6). In addition, we have three of the four neonates or infants, for whom details of burial context were available, buried lying on top of the arm and/or chest of the associated adult (see Tables 6 and 7), regardless of the age or sex of the adult. As such, it was clearly considered appropriate to protect the infant body by burying it within the adult space. The only exception was an infant from Baysrath (Sk 2403) who seems to have been buried adjacent to the adult's knee in a position that might seem suggestive of a lack of a close relationship between the two individuals. We should, however, remember at this point the tale included in the Life of St. Peter of Cornwall and Launceston, which related how the saint was interred in his coffin with the remains of his infant granddaughter lying on his knees (Hull and Sharpe 1985, 27 as quoted in Crawford 2007, 86).

In the Late Medieval burial ground at St Clemens in Copenhagen, Denmark, children (ages not provided) interred with adults were found lying on their chests and had been positioned with a degree of care. It was suggested that some of the individuals may not have been related and that burial with a child may have been an honour for an adult. It was also considered that the arrangement may have been mutually beneficial in that the adult could help ensure a 'safe journey' to the afterlife for the child (Jark Jensen 2017, 205). Since the infants included in the current study are from a variety of sites there is the possibility that the adults and children were connected, perhaps biologically, but nevertheless the evidence apparent in the Irish Medieval burials finds resonance with those in St Clemens and the arrangement may well have been viewed as being of mutual benefit to both individuals.

It is suggested that the simultaneous deaths of two or more individuals buried in contemporary multiple graves may have been viewed as a particularly devastating loss to a community that necessitated a shared grave and the physical connectivity between the bodies of the deceased. The violent deaths apparent in the adult male or adult male/adolescent pairings would clearly have been an untimely, and perhaps unnatural loss, and it is possible that the other multiple deaths were also viewed in this manner whether they had died as a result of tragic accidents or disease. The adult and juvenile burials contained the remains of mothers and newly birthed infants as well as adolescent boys transitioning to adulthood buried with adult men and who may well have died as a result of accidents during the course of day-to-day activities. The preponderance of middle-aged/older adults in association with the remaining juveniles is probably a representation of natural attrition within society when both older and younger members of society would have been most at risk of death from epidemic disease or famine. The law tracts suggest that Irish girls could get married as young as fourteen years of age (Kelly 1988, 88) so it is feasible that some of the middle-aged adults were grandparents. While it is possible that some grandparent and grandchild pairings are represented in this corpus of contemporary multiple burials it needs to be remembered that the majority of people buried within a Medieval Irish burial ground would have been socially interconnected through kinship ties. Those that were fostered would have had relationships with their foster family that were on a par to those with their biological relatives. As such, it is feasible that the individuals included within the double burials were not necessarily directly close biological relatives but this could only be tested using modern aDNA techniques.

Regardless of biological relatedness this corpus of contemporary multiple burials is suggestive of a closely-knit society in which adults and children alike 
were afforded equal burial rites. Unlike the situation for Early Anglo-Saxon England there is no evidence that the children in these burials were viewed as anything other than dead children who should be afforded Christian burial rites. The glimpses of care evident in the placement of infants within adult space or the placement of an adult hand on the body of the child, not to mention the entwining of adult hands or face-toface burial of two children all serve to remind us of the intentionality evident in these burials. The simultaneous death of two or more individuals would have been undoubtedly a major blow for these kin-based communities. Those responsible for the interment of the deceased were clearly at pains to afford them Christian burial rites but sometimes they went to greater efforts to personalise the burials. It is perhaps in these graves that we can find evidence of particularly close relationships between the dead, but also between the living and the dead.

\section{Acknowledgements}

We are grateful to the many archaeologists who kindly answered our queries about the contemporary double burials found during the course of their excavations Christine Baker (Fingal County Council), Dr Charles Mount (Archaeology and cultural heritage consultant), Donald Murphy (Archaeological Consultancy Services Unit), Edmond O'Donovan (Edmond O'Donovan \& Associates) and Robert O'Hara (Teagasc). Thanks are also due to Libby Mulqueeny, School of Natural and Built Environment, Queen's University Belfast, for her help with the illustrations. We are also very grateful to Mary Deevy, Transport Infrastructure Ireland (TII), for providing us with photographs taken during TIIfunded excavations

\footnotetext{
Notes

1. The eight sites examined but found not to include definitive contemporary multiple burials are - Ardreigh, Co. Kildare; Balriggan 121, Co. Louth; Borris, Co. Tipperary; Cross, Co. Galway; Holdenstown I, Co. Kilkenny; Knowth Site M, Co. Meath; Mullagh, Co. Longford; Owenbristy, Co. Galway. 2. The descriptive terminology of Sprague (2005, 86-9) was followed for the analysis of leg position according to the following definitions: Extended - The legs were straight and joined the torso at an angle of $0^{\circ}$; Semi-flexed - The angle between the torso and the axis of the femur lay between $0^{\circ}$ and $90^{\circ}$; Flexed - The angle between the axis of the trunk and femur was greater than $90^{\circ}$; Tightly flexed - The angle between the trunk and the axis of the femur approached $180^{\circ}$. This system was also applied to the lower leg to enable the degree of flexion at the knee to be ascertained.
}

\section{References}

Baker, C. 2010. Occam's Duck: three early medieval settlement cemeteries or ecclesiastical sites?, pp. 1-21 in Corlett, C. and Potterton, M. (eds.), Death and Burial in Early Medieval Ireland in the Light of Recent Archaeological Excavations (Research Papers in Irish Archaeology 2). Dublin: Wordwell.

Bhreathnach, E. 2014. Ireland in the Medieval World AD 4001000: Landscape, Kingship and Religion. Dublin: Four Courts Press.

Bowen, P. and Dawkes, G. 2011. E3801: Final Excavation Report of Phase 2 Excavations, A1/N1 Newry-Dundalk Link Road, Area 15, Site 116 (Vol. 1). Report prepared for the National Roads Authority/ Transport Infrastructure Ireland (Digital Repository of Ireland, The Discovery Programme, $<$ https:// doi.org/10.7486/DRI.bg25mv84h >).

Buckley, L. 2004. Appendix 3 - Skeletal report, pp. 89-132 in Russell, I., 01E0039: Northern Motorway Road Project Gormanstown - Monasterboice. Final Report - Claristown 2. Report prepared for the National Roads Authority/ Transport Infrastructure Ireland (Digital Repository of Ireland, The Discovery Programme, < https://doi. org/10.7486/DRI.5425zr452 >).

Buikstra, J. E. and Ubelaker, D. H. (eds.) 1994. Standards for Data Collection from Human Skeletal Remains (Arkansas Archeological Survey Research Series 44). Arkansas: Arkansas Archeological Survey.

Chamberlain, A. 2006. Demography in Archaeology. Cambridge: Cambridge University Press.

Channing, J. 2009. E2798: Final Report of N6 Kilbeggan to Kinnegad Dual Carriageway: Archaeological Resolution Ballykilmore 6, Ballykilmore Townland, Co. Westmeath (Vol. 1). Report prepared for the National Roads Authority/ Transport Infrastructure Ireland (Digital Repository of Ireland, The Discovery Programme, < https://doi. org/10.7486/DRI.v4065r193 >).

Channing, J. 2012. E2517: N9/N10 Kilcullen to Waterford Scheme: Phase 2: Waterford to Knocktopher - Archaeological Resolution Baysrath Townland, Co. Kilkenny (Vol. 1). Unpublished report prepared for the National Roads Authority/ Transport Infrastructure Ireland.

Channing, J. 2014. Ballykilmore, Co. Westmeath: continuity of an early medieval graveyard, pp. 23-38 in Corlett, C. and Potterton, M. (eds.), The Church in Early Medieval Ireland in the Light of Recent Archaeological Excavations. Dublin: Wordwell Ltd.

Charles-Edwards, T. 1992. The pastoral role of the church in the early Irish law, pp. 63-77 in Blair, J. and Sharpe, R. (eds.), Pastoral Care Before the Parish. Leicester: Continuum International Publishing.

Clarke, L. 2004. 02E0462: Report on the Archaeological Resolution of a Multi-Period Burial, Settlement E Industrial Site at Johnstown 1, Enfield, County Meath (Vol. 3). Report prepared for the National Roads Authority/ Transport Infrastructure Ireland (Digital Repository of Ireland, The Discovery Programme, < https://doi.org/10.7486/DRI. np19gq96z $>$ ).

Clarke, L. 2010. Johnstown 1, Co. Meath: a multi-period burial, settlement and industrial site, pp. 61-75 in Corlett, C. and Potterton, M. (eds.), Death and Burial in Early Medieval Ireland in the Light of Recent Archaeological Excavations (Research Papers in Irish Archaeology 2). 
Dublin: Wordwell.

Clarke, L. and Carlin, N. 2008a. E3088: M3 Clonee-North of Kells, Report on the Archaeological Excavation of Ardsallagh 1, Co. Meath. Report prepared for the National Roads Authority/ Transport Infrastructure Ireland (Digital Repository of Ireland, The Discovery Programme, < https:// doi.org/10.7486/DRI.8910z835k >).

Clarke, L. and Carlin, N. 2008b. Living with the dead at Johnstown 1: an enclosed burial, settlement and industrial site, pp. 55-85 in Carlin, N. Clarke, L. and Walsh, F., The Archaeology of Life and Death in the Boyne Floodplain: The Linear Landscape of the M4, Kinnegad-Enfield-Kilcock Motorway (NRA Scheme Monographs 2). Dublin: National Roads Authority.

Clarke, L. and Carlin, N., 2009. From focus to locus: a window upon the development of a funerary landscape, pp. 1-20 in Deevy, M. B. and Murphy, D. (eds.), Places Along the Way: First Findings on the M3 (NRA Scheme Monographs 5). Dublin: The National Roads Authority.

Cotter, E. 2011. 03E0461: N7 Heath-Mayfield Motorway Scheme: Archaeological Resolution. Final report - Site D, Morett Townland, Co. Laois. Report prepared for the National Roads Authority/ Transport Infrastructure Ireland (Digital Repository of Ireland, The Discovery Programme, < https:// doi.org/10.7486/DRI.0z70pb18m >).

Coughlan, J. 2009. Appendix 16. Human Skeletal Report, pp. 295-331 in Muñiz Pérez, M., E2123: N6 Galway to East Ballinasloe. Final Report - Treanbaun, Co. Galway - Bronze Age Site and Early Medieval Burials and Enclosure. Report prepared for the National Roads Authority/ Transport Infrastructure Ireland (Digital Repository of Ireland, The Discovery Programme, < https://doi.org/10.7486/ DRI.9p29cr13n >).

Crawford, S. 2007. Companions, co-incidences or chattels? Children in the early Anglo-Saxon multiple burial ritual, pp. 83-92 in Crawford, S. and Shepherd, G. (eds.), Children, Childhood and Society (BAR International Series 1696). Oxford: Archaeopress.

Curtis, E. and McDowell, R. B. 1943. Irish Historical Documents 1172-1922. London: Methuen \& Co. Ltd.

Daily Mail Reporter. 2008. Football-mad brothers are buried together in double Manchester United coffin. Mail Online < http://www.dailymail.co.uk/news/article-1030134/ Football-mad-brothers-buried-double-Manchester-Unitedcoffin.html >.

Daniell, C. 1997. Death and Burial in Medieval England. London: Routledge.

Delaney, F. 2012. Archaeological Excavation Report Sawpit Lane, Tuam, Co. Galway - Early medieval graveyard and enclosure. Eachtra Journal 16, 1-97.

Dillon, M. 1936. The relationship of mother and son, of father and daughter, and the law of inheritance with regard to women, pp. 129-79 in Thurneysen, R., Power, N., Dillon, M., Mulchrone, K., Binchy, D. A., Knoch, A. and Ryan, J., Studies in Early Irish Law. Dublin: Royal Irish Academy.

Donnelly, C. J. and Murphy, E. M. 2018. Violence in later medieval Ireland: the osteoarchaeological evidence and its historical context, pp. 108-28 in Campbell, E., Fitzpatrick, E. and Horning, A. (eds.), Becoming and Belonging in Ireland AD c. 1200-1600: Essays in Identity and Cultural Practice. Cork: Cork University Press.

Downham, C. 2018. Medieval Ireland. Cambridge: Cambridge University Press.
Duday, H. 2009. The Archaeology of the Dead: Lectures in Archaeothanatology. Oxford: Oxbow Books.

Eogan, J. 2010. Excavation of an unenclosed early medieval cemetery at Bettystown, Co. Meath, pp. 103-116 in Corlett, C. and Potterton, M. (eds.), Death and Burial in Early Medieval Ireland in the Light of Recent Archaeological Excavations (Research Papers in Irish Archaeology 2). Dublin: Wordwell.

Fibiger, L. 2008. Report on the Human Skeletal Remains from Johnstown 1, Co. Meath. Appendix on CD with Carlin, N. Clarke, L. and Walsh, F., The Archaeology of Life and Death in the Boyne Floodplain: The Linear Landscape of the M4, Kinnegad-Enfield-KilcockMotorway (NRA Scheme Monographs 2). Dublin: National Roads Authority.

Fibiger, L. and Seaver, M. 2016. Population, death and burial pp. 61-86 in Seaver, M., Meitheal: The Archaeology of Lives, Labours and Beliefs at Raystown, Co. Meath (TII Heritage 4). Dublin: Transport Infrastructure Ireland.

Fitzsimons, F. 2001. Fosterage and gossiprid in Late Medieval Ireland: some new evidence, pp. 138-49 in Duffy, P. J., Edwards, D. and FitzPatrick, E. (eds.), Gaelic Ireland c.1250-c. 1650: Land, Lord and Settlement. Dublin: Four Courts Press.

Flynn, C. 2011. E3580: N7 Castletown to Nenagh Road Improvement Scheme - Camlin 3 Final Report (Vol. 1). Report prepared for the National Roads Authority/ Transport Infrastructure Ireland (Digital Repository of Ireland, The Discovery Programme, < https://doi.org/10.7486/DRI. q237x674t >).

Fry, S. L. 1999. Burial in Early Medieval Ireland 900-1500: A Review of the Written Sources. Dublin: Four Courts Press.

Gardeła, L. and Duma, P. 2013. Untimely death: atypical burials of children in early and late medieval Poland. World Archaeology 45, 314-32.

Geber, J. 2015. Comparative study of perimortem weapon trauma in two Early Medieval skeletal populations (AD 400-1200) from Ireland. International Journal of Osteoarchaeology 25, 253-64.

Ginnell, L. 1993 [1894]. The Brehon Laws: A Legal Handbook. Littleton: Fred B. Rothman.

Hanawalt, B. A. 1986. The Ties that Bound: Peasant Families in Medieval England. Oxford: Oxford University Press.

Hertz, R. 1905. Contribution à une étude sur la représentation collective de la mort. L'Année Sociologique (1896/18971924/1925) 10, 48-137.

Hull, P. and Sharpe, R. 1985. Peter of Cornwall and Launceston. Cornish Studies 13, 5-53.

Jark Jensen, J. 2017. Emotional act, superstition or ritual? Evidence from child burials in the Medieval period. A case study from St Clemens Churchyard, Copenhagen, Denmark, pp. 197-210 in Murphy, E. and Le Roy, M. (eds.), Children, Death and Burial: Archaeological Discourses (SSCIP Monograph 5). Oxford: Oxbow Books.

Keating, D. 2009a. Appendix 11: Analysis of the human skeletal remains, in Wiggins, K. and Kane, E., E2220: M7 Portlaoise-Castletown/M8 Portlaoise-Cullahill Motorway Scheme. Report on the Archaeological Excavation of Bushfield or Maghernaskeagh/Lismore 1, Co. Laois. Report prepared for the National Roads Authority/ Transport Infrastructure Ireland (Digital Repository of Ireland, The Discovery Programme, < https://doi.org/10.7486/DRI.7w62tq037 >).

Keating, D. 2009b. E2170: M7 Portlaoise-Castletown/M8 Portlaoise-Cullahill Motorway Scheme - An Analysis of the Human Skeletal Remains from Parknahown 5, Co. Laois 
(A015/060) (Vol. 3). Report prepared for the National Roads Authority/ Transport Infrastructure Ireland (Digital Repository of Ireland, The Discovery Programme, < https:// doi.org/10.7486/DRI.cn700j93q >).

Kelly, F. 1988. A Guide to Early Irish Law (Early Irish Law Series Vol. 3). Dublin: Dublin Institute for Advanced Studies.

Knüsel, C. J. 2014. Crouching in fear: terms of engagement for funerary remains. Journal of Social Archaeology 14, 26-58.

Lalonde, S. 2009. Appendix 10 - Human remains report, pp. 99-156 in Wilkins, B. and Lalonde, S., E2046: N6 Galway to Ballinasloe Scheme, Contract 2. Final Report on Archaeological Investigations at Site E2046, an Enclosure Ditch and Cemetery in the Townland of Carrowkeel, Co. Galway (Vol. 1). Report prepared for the National Roads Authority/ Transport Infrastructure Ireland (Digital Repository of Ireland, The Discovery Programme, < https://doi.org/10.7486/ DRI.63968n89w >).

Lehane, J., Muñiz Pérez, M., O’Sullivan, J. and Wilkins, B. 2010. Three cemetery excavations in County Galway at Carrowkeel, Treanbaun and Owenbristy, pp. 139-56 in Corlett, C. and Potterton, M. (eds.), Death and Burial in Early Medieval Ireland in the Light of Recent Archaeological Excavations (Research Papers in Irish Archaeology 2). Dublin: Wordwell.

McKenzie, C. J. and Murphy, E. M. 2018. Life and Death in Medieval Gaelic Ireland: The Ballyhanna Skeletons. Dublin: Four Courts Press.

McKenzie, C., Murphy, E. M. and Donnelly, C. J. 2015. Conclusions - ordinary lives: the Medieval Gaelic people of Ballyhanna, pp. 161-7 in McKenzie, C. J., Murphy, E. M. and Donnelly, C. J. (eds.), The Science of a Lost Medieval Gaelic Graveyard - The Ballyhanna Research Project (TII Heritage 2). Dublin: Transport Infrastructure Ireland.

Meyer, K. 1906. The Death-tales of the Ulster Heroes (Royal Irish Academy Todd Lecture Series 14). Dublin: Figgis and Co.

Moorrees, C. F. A, Fanning, E. A. and Hunt, E. E. 1963. Formation and resorption of three deciduous teeth in children. American Journal of Physical Anthropology 21, 20513.

Mount, C. 2010. Excavation of an early medieval promontory fort and enclosed cemetery at Knoxspark, Co. Sligo, pp. 187-216 in Corlett, C. and Potterton, M. (eds.), Death and Burial in Early Medieval Ireland in the Light of Recent Archaeological Excavations (Research Papers in Irish Archaeology 2). Dublin: Wordwell.

Muñiz Pérez, M. 2009. E2123: N6 Galway to East Ballinasloe. Final Report - Treanbaun, Co. Galway - Bronze Age Site and Early Medieval Burials and Enclosure. Report prepared for the National Roads Authority/ Transport Infrastructure Ireland (Digital Repository of Ireland, The Discovery Programme, < https://doi.org/10.7486/DRI.9p29cr13n >).

Murphy, E. M. 2015. Lives cut short - insights from the osteological and palaeopathological analysis of the Ballyhanna juveniles, pp. 103-20 in McKenzie, C. J., Murphy, E. M. and Donnelly, C. J. (eds.), The Science of a Lost Medieval Gaelic Graveyard - The Ballyhanna Research Project (TII Heritage 2). Dublin: Transport Infrastructure Ireland.

Murphy, E. M. 2017. Atypical burial practice and juvenile age-at-death in later medieval Gaelic Ireland: The evidence from Ballyhanna, Co. Donegal, pp. 227-48 in Murphy, E. and Le Roy, M. (eds.), Children, Death and Burial: Archaeological Discourses. Oxford: Oxbow Books.

Ní Chonaill, B. 1997. Fosterage: Child-rearing in Medieval
Ireland. History Ireland 5, 28-31.

Ní Chonaill, B. forthcoming. Child-centred law in Medieval Ireland in Davis, R. and Dunne, T. (eds.), The Empty Throne: Childhood and the Crisis of Modernity. Cambridge: Cambridge University Press < http://eprints.gla.ac.uk/3812/ >.

Nicholls, K. W. 1993. Gaelic society and economy, pp. $397-$ 438 in Cosgrove, A. (ed.), A New History of Ireland, Volume 2: Medieval Ireland, 1169-1534 (second edition). Oxford: Clarendon Press.

O'Connell, A. 2014. The early church in Fingal: evidence from Church Road, Lusk, Co. Dublin, pp. 173-86 in Corlett, C. and Potterton, M. (eds.), The Church in Early Medieval Ireland in the Light of Recent Archaeological Excavations. Dublin: Wordwell.

Ó Cróinín, D. 2017. Early Medieval Ireland 400-1200 (second edition). London: Routledge.

O’Donovan, E. 2005. Archaeological Excavations at Mount Gamble, Townparks, Swords, Co. Dublin. Unpublished report prepared for Margaret Gowan Ltd.

O'Donovan, E. 2014. Excavations at the lost church of Drumkay, Glebe, Co. Wicklow, pp. 187-224 in Corlett, C. and Potterton, M. (eds.), The Church in Early Medieval Ireland in the Light of Recent Archaeological Excavations. Dublin: Wordwell.

O'Donovan, E. 2016. Archaeological excavations on Mount Gamble Hill: evidence for a new early medieval church in Swords?, pp. 13-38 in Duffy, S. (ed.), Medieval Dublin XV (Friends of Medieval Dublin Symposium 15). Dublin: Four Courts Press.

O’Donovan, E. and Geber, J. 2010. Excavations on Mount Gamble Hill, Swords, Co. Dublin, pp. 227-38 in Corlett, C. and Potterton, M. (eds.), Death and Burial in Early Medieval Ireland in the Light of Recent Archaeological Excavations. Dublin: Wordwell Ltd.

O'Hara, R. 2009. Collierstown 1: A Late Iron Age - Early Medieval enclosed cemetery, pp. 83-100 in Deevy, M. B. and Murphy, D. (eds.), Places Along the Way: First Findings on the M3 (NRA Scheme Monographs 5). Dublin: The National Roads Authority.

O'Neill, T. 2009. E2170: M7 Portlaoise-Castletown/M8 PortlaoiseCullahill Motorway Scheme - Report on the Archaeological Excavation of Parknahown 5, Co. Laois (Vol. 1). Report prepared for the National Roads Authority/ Transport Infrastructure Ireland (Digital Repository of Ireland, The Discovery Programme, < https://doi.org/10.7486/DRI. d21844297 >).

Parker Pearson, M. 2003. The Archaeology of Death and Burial. Stroud: The History Press (2009 reprint).

Piontelli, A. 2002. Twins: From Fetus to Child. London: Routledge.

Powers, N. 2004. Augherskea: Report on human remains excavated from site 1A/23/1 during the BGE Gas Pipeline project August November 2002. Unpublished report prepared for Margaret Gowen and Co Ltd.

Randolph-Quinney, P. 2008. Appendix 11: Human remains in Clarke, L. and Carlin, N., E3088: M3 Clonee-North of Kells, Report on the Archaeological Excavation of Ardsallagh 1, Co. Meath. Report prepared for the National Roads Authority/ Transport Infrastructure Ireland (Digital Repository of Ireland, The Discovery Programme, < https://doi. org/10.7486/DRI.8910z835k >).

Randolph-Quinney, P. 2009. Appendix 8.1 - Human remains in Channing, J., E2798: Final Report of N6 Kilbeggan to 
Kinnegad Dual Carriageway: Archaeological Resolution Ballykilmore 6, Ballykilmore Townland, Co. Westmeath (Vol. 2). Report prepared for the National Roads Authority/ Transport Infrastructure Ireland (Digital Repository of Ireland, The Discovery Programme, $<$ https://doi. org/10.7486/DRI.v6936n03d >).

Rosenthal, J. T. 1996. Old Age in Late Medieval England. Philadelphia: University of Pennsylvania Press.

Russell, I. R., Mossop, M. and Corcoran, E. 2002. Claristown 2: a cemetery and later cairn; excavations for the Drogheda Bypass - M1 Motorway. Riocht na Midhe 13, 23-31.

Russell, I. 2004. 01E0039: Northern Motorway Road Project Gormanstown - Monasterboice. Final Report - Claristown 2. Report prepared for the National Roads Authority/ Transport Infrastructure Ireland (Digital Repository of Ireland, The Discovery Programme, < https://doi. org/10.7486/DRI.5425zr452 >).

Scheuer, L. and Black, S. 2000. Developmental Juvenile Osteology. London: Academic Press.

Seaver, M. 2016. Meitheal: The Archaeology of Lives, Labours and Beliefs at Raystown, Co. Meath (TII Heritage 4). Dublin: Transport Infrastructure Ireland.

Smith, B. H. 1991. Standards of human tooth formation and dental age assessment, pp. 143-68 in Kelley, M. A. and Larsen, C. S. (eds.), Advances in Dental Anthropology. New York: Wiley-Liss Inc.

Sprague, R. 2005. Burial Terminology: A Guide for Researchers. Lanham: AltaMira Press.

Stoodley, N. 2002. Multiple burials, multiple meanings? Interpreting the Early Anglo-Saxon multiple interment, pp. 103-10 in Lucy, S. and Reynolds, A. (eds.), Burial in Early Medieval England and Wales (Society for Medieval Archaeology Monograph 17). London: Maney Publishing. Svensson, K. 2011. Section 4.2.1 Human bone report, pp. 159-310 in Flynn, C., E3580: N7 Castletown to Nenagh Road Improvement Scheme - Camlin 3 Final Report (Vol. 1). Report prepared for the National Roads Authority/ Transport Infrastructure Ireland (Digital Repository of Ireland, The
Discovery Programme, < https://doi.org/10.7486/DRI. q237x674t >).

Svensson, K. 2012. 4.10 Skeletal human remains, pp. 335-98 in Channing, J., E2517: N9/N10 Kilcullen to Waterford Scheme: Phase 2: Waterford to Knocktopher - Archaeological Resolution Baysrath Townland, Co. Kilkenny (Vol. 1). Unpublished report prepared for the National Roads Authority/ Transport Infrastructure Ireland.

Wiggins, K. and Kane, E. 2009a. E2220: M7 PortlaoiseCastletown/M8 Portlaoise-Cullahill Motorway Scheme. Report on the Archaeological Excavation of Bushfield or Maghernaskeagh/Lismore 1, Co. Laois. Report prepared for the National Roads Authority/ Transport Infrastructure Ireland (Digital Repository of Ireland, The Discovery Programme, < https://doi.org/10.7486/DRI.7w62tq037 >).

Wiggins, K. and Kane, E. 2009b. E2171: M7 PortlaoiseCastletown/M8 Portlaoise-Cullahill Motorway Scheme, Report on the Archaeological Excavation of Killeany 1, Co. Laois. Report prepared for the National Roads Authority/ Transport Infrastructure Ireland (Digital Repository of Ireland, The Discovery Programme, < https://doi.org/10.7486/DRI. d7925w97f $>$ ).

Wiggins, K. 2014. An early medieval ditched enclosure with burials and cereal-drying kilns at Killeany, Co. Laois, pp. 273-86 in Corlett, C. and Potterton, M. (eds.), The Church in Early Medieval Ireland in the Light of Recent Archaeological Excavations. Dublin: Wordwell.

Wilkins, B. and Lalonde, S. 2008. An Early Medieval settlement/cemetery at Carrowkeel, Co. Galway. The Journal of Irish Archaeology 17, 57-83.

Wilkins, B. and Lalonde, S. 2009. E2046: N6 Galway to Ballinasloe Scheme, Contract 2. Final Report on Archaeological Investigations at Site E2046, an Enclosure Ditch and Cemetery in the Townland of Carrowkeel, Co. Galway (Vol. 1). Report prepared for the National Roads Authority/ Transport Infrastructure Ireland (Digital Repository of Ireland, The Discovery Programme, < https:// doi.org/10.7486/DRI.63968n89w >). 